\title{
The Removal of Binary Mixture of Dyes by Heterogeneous Fenton Oxidation: Kinetics, Product Identification and Toxicity Assessment
}

\author{
John Elisa Kumar, ${ }^{1}$ Tsungom Mulai, ${ }^{1}$ Wanshanlang Kharmawphlang, ${ }^{1}$ \\ Rajeshwar Nath Sharan ${ }^{2}$ and Mihir Kumar Sahoo ${ }^{1^{\star}}$ \\ ${ }^{1}$ Centre for Advanced Studies in Chemistry, Department of Chemistry, North-Eastern Hill University, \\ Shillong- 793 022, India \\ ${ }^{2}$ Radiation \& Molecular Biology Unit, Department of Biochemistry, North-Eastern Hill University, \\ Shillong- 793 022, India \\ *Corresponding author: E-mail: mksahoo@nehu.ac.in; mihirs2107@gmail.com \\ Tel.: +91-364-2722632; Cell: +91-9436706767; Fax: +91-364-2551634
}

Received: 03-19-2021

\begin{abstract}
The removal of mixture of two azo dyes, Acid blue 29 and Ponceau xylidine, was studied by heterogeneous Fenton and Fenton-type processes using hydrogen peroxide and sodium persulphate as oxidants in the presence of and nano and micro- $-\mathrm{Fe}_{2} \mathrm{O}_{3}$ particles as catalysts. The synthesised nano- $\mathrm{Fe}_{2} \mathrm{O}_{3}$ particles were characterised using analytical techniques viz. FT-IR, TEM, EDX, powder XRD and VSM. We have examined the effects of particle size on the COD removal efficiency and the reusability of the catalyst after optimising $\mathrm{pH}$, and concentrations of catalyst and oxidant. Combination of nano- $\mathrm{Fe}_{2} \mathrm{O}_{3}$ and hydrogen peroxide possessed higher $\mathrm{COD}$ removal efficiency, which was accelerated in acidic $\mathrm{pH}$ and inhibited at $\mathrm{pH}>6$. Total consumption of hydrogen peroxide confirmed the efficiency of the optimised parameters. The mechanism of the formation of intermediate ions and products are proposed. COD removal and consumption of hydrogen peroxide follow pseudo-first-order kinetics. The toxicity of the solutions was assessed using Aliivibrio fischeri light loss and Escherichia coli growth inhibition assays. Both the assays showed different toxicity levels for the same solution.
\end{abstract}

Keywords: Binary mixture of dyes; Heterogeneous Fenton processes; COD removal kinetics; Identification of ions and products; Toxicity assessment using Escherichia coli and Alivibrio fischeri

\section{Introduction}

The wastewater generated by the textile industries usually contains a higher concentration of Chemical Oxygen Demand (COD), Biochemical Oxygen Demand (BOD), alkalinity and colour, ${ }^{1}$ which should be normalised before releasing into the water bodies to contain pollution. Advanced Oxidation Processes (AOPs), which involve in situ generation of hydroxyl radicals, have achieved the above goals to a great extent. ${ }^{2-4}$ The oldest AOPs, involving activation of hydrogen peroxide (HP) and sodium persulphate (SPS) to generate hydroxyl and sulphate radi$\mathrm{cals}^{5-7}$ using $\mathrm{Fe}^{2+}$ as a catalyst, are popularly known as Fenton $\left(\mathrm{Fe}^{2+} / \mathrm{HP}\right)$ and Fenton-type process $\left(\mathrm{Fe}^{2+} / \mathrm{SPS}\right)$ (Eqs. (1) and (2)). Apart from being a simple and efficient reaction requiring no electrical energy input, the $\mathrm{Fe}^{2+} / \mathrm{HP}$ pro- cess requires only a catalytic amount of $\mathrm{Fe}^{2+}$ since it is regenerated from the $\mathrm{Fe}^{3+}$ ion in a process called Fenton-like reaction (Eq. (3)). ${ }^{8}$

$$
\begin{aligned}
& \mathrm{Fe}^{2+}+\mathrm{H}_{2} \mathrm{O}_{2}+\mathrm{H}^{+} \rightarrow \mathrm{Fe}^{3+}+\mathrm{H}_{2} \mathrm{O}+\mathrm{HO}^{\circ} \\
& \mathrm{Fe}^{2+}+\mathrm{S}_{2} \mathrm{O}_{8}^{2-} \rightarrow \mathrm{Fe}^{3+}+\mathrm{SO}_{4}^{--}+\mathrm{SO}_{4}^{2-} \\
& \mathrm{Fe}^{3+}+\mathrm{H}_{2} \mathrm{O}_{2} \rightarrow \mathrm{Fe}^{2+}+\mathrm{HO}_{2}^{-}+\mathrm{H}^{+}
\end{aligned}
$$

These advantages are masked by its narrow operational $\mathrm{pH}$ range, and sludge generation at the end of the process. ${ }^{5,9}$ So, a search for a low cost and stable catalyst, which can be easily separated from the reaction medium and reused in successive cycles, thereby reducing the cost of operation, is needed. A heterogeneous catalyst has been 
shown to meet the requirements mentioned above and, therefore, can be used in the Fenton process, the heterogeneous Fenton process. Among the various heterogeneous catalysts, zero-valent iron nano-particles, ${ }^{10,11}$ and iron oxide minerals ${ }^{12-15}$ have been widely used for environmental remediation. Iron is fixed in the structure of a heterogeneous catalyst that activates the oxidant (Eq. (4)) over a broad range of $\mathrm{pH}$ values depending on the point of zero charge (PZC) of the catalyst. ${ }^{16}$ Hence, the biggest advantage of the heterogeneous over homogeneous Fenton process is that the catalyst can be separated by an external magnet.

$$
\equiv \mathrm{Fe}^{2+}+\mathrm{H}_{2} \mathrm{O}_{2}+\mathrm{H}^{+} \rightarrow \equiv \mathrm{Fe}^{3+}+\mathrm{H}_{2} \mathrm{O}+\mathrm{HO}^{\circ}
$$

(Where $\equiv$ represents the surface of the catalyst)

Most publications in this domain have utilized low concentrations of dyes varying from 10 to $30 \mathrm{ppm}$. Although the literature is rich in reports on degradation of individual dyes by different AOPs, that for mixture of dyes is scanty even though textile industries invariably use mixture of dyes. Keeping this lacuna in mind, we decided to study the removal of mixture of two dyes, viz. Acid Blue 29 $\mathrm{AB})$ and Ponceau Xylidine (PX) at higher concentrations (92 ppm and $72 \mathrm{ppm}$, respectively, equivalent to $0.15 \mathrm{mM}$ for both) by heterogeneous Fenton and Fenton-type processes. COD removal efficiency $\left(\mathrm{COD}_{\text {eff }}\right)$ was used as an indicator for the removal of dyes. In this study, two types of iron oxide particles as catalysts: nano- $\mathrm{Fe}_{2} \mathrm{O}_{3}$ (synthesised, average particle size $26-35 \mathrm{~nm}$ ) and micro- $\mathrm{Fe}_{2} \mathrm{O}_{3}$ particles (commercially available, $<5 \mu \mathrm{m}$ ) and two different oxidants, i.e. HP and SPS, were used. AB and PX were selected as the model dye pollutants because of their extensive use in textile industries for dyeing wool, cotton, silk, polyester and rayon etc. They are also used in paint, ink, plastic and leather industries. Moreover, the dyes, being azo dyes, are recalcitrant and carcinogenic due to the presence of $\mathrm{N}=\mathrm{N}-$ bond. ${ }^{17,18}$ Since the activation of HP and SPS depends on the specific surface area of the catalyst; we proposed to investigate the ability of iron (III) oxide nano-particles $\left(\mathrm{n}-\mathrm{Fe}_{2} \mathrm{O}_{3}\right)$ and micro- $\mathrm{Fe}_{2} \mathrm{O}_{3}\left(\mathrm{~m}-\mathrm{Fe}_{2} \mathrm{O}_{3}\right)$ particles to decompose HP and SPS and produce hydroxyl and sulphate radicals. This study also examined the influence of catalyst loading, HP dosage, and $\mathrm{pH}$ on the efficiency of the process. Apart from these in this study, we attempted to optimize the operational parameters to maximize HP efficiency by ensuring its total consumption in the process, COD removal and HP consumption kinetics. Assessment of the effect of residual hydrogen peroxide on the COD removal efficiency was another important objective of the study. Different ions and end products formed in the process were analysed by Ion chromatography. The degradation mechanism of the mixture of dyes based on end-product analysis and supported by literature data has been proposed.

Despite the enhanced efficiency of the AOPs, complete mineralisation of the organic compounds may not always be possible. Under such a situation, the intermedi- ate oxidation by-products may contribute to increased toxicity. ${ }^{19}$ On the contrary, there are instances of increased toxicity of the solutions even when Fenton and Fenton-type processes achieve mineralisation to the extent of $>90 \%$. 7,20 Therefore, it is essential to test the toxicity of industrial wastewater after treatment, after a complete mineralisation is achieved. Some authors have used Alivibrio fischeri and some Escherichia coli for the toxicity assessment. But no attempt has been made to compare the toxicity of a given sample using these two assessment methods. In this study, we have compared the toxicity of the pure dye solution and the solutions obtained at different stages of the treatment process.

\section{Materials and Methods}

\section{1. Chemicals and Materials}

The diazo dye, Acid Blue 29 (Synonym: Amacid Navy Blue B; Cetil Black M; Fabracid Navy S-BL; Mordant Blue 82; CI number: 20460; molecular formula: $\mathrm{C}_{22} \mathrm{H}_{14} \mathrm{~N}_{6} \mathrm{Na}_{2} \mathrm{O}_{9} \mathrm{~S}_{2}$; molecular weight: $616.49\left(\mathrm{~g} \mathrm{~mol}^{-1}\right)$; $\lambda_{\max }=602 \mathrm{~nm} ; \mathrm{pH}$ of the dye solution in water: 6.7) and the anionic diazo dye, Ponceau Xylidine (Synonym: 1-(2,4-xylylazo)-2-naphthol-3,6-disulphonicacid disodium salt; C.I. number: 16150; molecular formula: $\mathrm{C}_{18} \mathrm{H}_{14} \mathrm{~N}_{2} \mathrm{Na}_{2} \mathrm{O}_{7} \mathrm{~S}_{2}$; molecular weight: $480.42\left(\mathrm{~g} \mathrm{~mol}^{-1}\right)$; $\lambda_{\max }=504 \mathrm{~nm} ; \mathrm{pH}$ of the dye solution in water: 6.2) were procured from Sigma Aldrich (Germany). The molecular structures of AB 29 and PX are shown in Fig. 1.
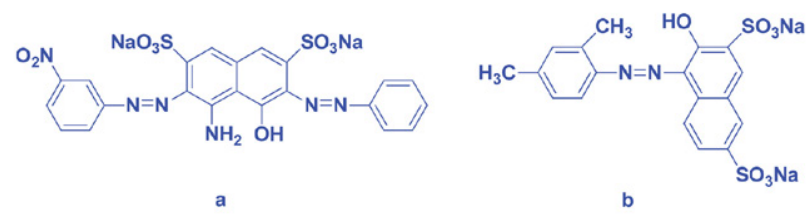

Figure 1. Structures of Acid blue 29 (a) and Ponceau xylidine (b).

The other chemicals viz. sulphuric acid $\left(\mathrm{H}_{2} \mathrm{SO}_{4}, \mathrm{GR}\right)$, sodium hydroxide $(\mathrm{NaOH}, \mathrm{GR})$, hydrogen peroxide $\left(\mathrm{H}_{2} \mathrm{O}_{2}\right.$, $30 \% \mathrm{w} / \mathrm{w}$, purified), sodium peroxodisulphate $\left(\mathrm{Na}_{2} \mathrm{~S}_{2} \mathrm{O}_{8}\right.$, for analysis), iron (II) sulphate $\left(\mathrm{FeSO}_{4} \cdot 7 \mathrm{H}_{2} \mathrm{O}\right.$, $\mathrm{GR})$, iron (II) chloride anhydrous $\left(\mathrm{FeCl}_{2}\right.$, purified), iron (III) chloride tetrahydrate $\left(\mathrm{FeCl}_{3} \cdot 4 \mathrm{H}_{2} \mathrm{O}\right)$, hydrochloric acid ( $\mathrm{HCl}$, min $35 \% \mathrm{GR})$, nitric acid $\left(\mathrm{HNO}_{3}\right.$, min $\left.65 \% \mathrm{GR}\right)$, and methanol $\left(\mathrm{CH}_{3} \mathrm{OH}, \mathrm{GR}\right)$ were obtained from Merck. Ethanol (absolute, 99.9\%) was obtained from Changshu Yangyuan Chemical, China. Solution 1' (mercuric sulphate and sulphuric acid) and 'Solution 2' for low range COD (silver sulphate, chromic acid, sulphuric acid and demineralised water) required for the determination of COD were supplied by HACH, USA. The chemicals used for ion chromatographic analysis were sodium hydroxide $(\mathrm{NaOH}, 50-$ $52 \%$ in water, Sigma), methane sulphonic acid $\left(\mathrm{CH}_{3} \mathrm{SO}_{3} \mathrm{H}\right.$, 
HIMEDIA), acetonitrile $\left(\mathrm{CH}_{3} \mathrm{CN}\right.$, HPLC grade, HIMEDIA), ammonium acetate $\left(\mathrm{CH}_{3} \mathrm{COONH}_{4}\right.$, Merck, Emparta ACS). All the chemicals were used as received.

\section{2. Catalysts}

\section{2. 1. $\mathrm{Fe}_{2} \mathrm{O}_{3}$ Micro-particles}

Iron (III) oxide powder $(<5 \mu \mathrm{m})$, i.e. $\mathrm{m}-\mathrm{Fe}_{2} \mathrm{O}_{3}$ used as one of the catalysts in the heterogeneous process, was supplied by Sigma-Aldrich.

\section{2. 2. $\mathrm{Fe}_{2} \mathrm{O}_{3}$ Nano-particles}

Iron (III) oxide nano-particles $\left(n-\mathrm{Fe}_{2} \mathrm{O}_{3}\right)$ were synthesised by chemical co-precipitation of $\mathrm{Fe}(\mathrm{II})$ and $\mathrm{Fe}$ (III) ions as described earlier. ${ }^{21}$ Briefly, $3.1 \mathrm{~g}$ of $\mathrm{FeCl}_{2} \cdot 4 \mathrm{H}_{2} \mathrm{O}$ and $5.2 \mathrm{~g}$ of $\mathrm{FeCl}_{3}$ (molar ratio of 1:2) were successively added to $25 \mathrm{~mL}$ of deionised water acidified with $0.85 \mathrm{~mL}$ of $12.1 \mathrm{~N} \mathrm{HCl}$ with constant stirring. The resulting solution was added dropwise to $250 \mathrm{~mL}$ of $1.5 \mathrm{M} \mathrm{NaOH}$ solution under vigorous stirring when an instant black precipitate was observed. The paramagnetic character of the particles was checked in situ by placing a magnet near the deposit. The precipitate was filtered using a vacuum pump after continuously stirring for $6 \mathrm{~h}$ and washed with deionised water until neutral $\mathrm{pH}$ was achieved. Finally, the precipitate was washed with ethanol, dried, ground and stored. The black precipitate turned light brown after drying due to calcination.

The surface functional groups of the prepared $n-\mathrm{Fe}_{2} \mathrm{O}_{3}$ particles were qualitatively identified using the FTIR spectrum (Bruker, Model: Alpha II). The morphology of the synthesised $n-\mathrm{Fe}_{2} \mathrm{O}_{3}$ was determined by transmission electron microscopy (TEM) with an instrument (JEOL, JEM-2100) operating at $200 \mathrm{kV}$. The purity of n$\mathrm{Fe}_{2} \mathrm{O}_{3}$ was confirmed by energy dispersive $\mathrm{X}$-rays (EDX) analysis. To check the crystallinity, powder X-ray diffraction (XRD) patterns of the dried $\mathrm{n}-\mathrm{Fe}_{2} \mathrm{O}_{3}$ were recorded in reflection mode using a high resolution diffractometer (GNR Analytical Instrument, Explorer, Italy) with $\mathrm{CuKa}$ radiation $(\lambda=1.54 \AA)$ within the $2 \theta$ values ranging from 20 to $80^{\circ}$ with a step size of $0.05^{\circ}$ and step time of $2 \mathrm{~min}$. The operating voltage and current were $40 \mathrm{kV}$ and $35 \mathrm{~mA}$, respectively. The vibrating sample magnetometry (VSM) analysis was performed using Vibrating Sample Magnetometer (Lakeshore, 7410 series) to confirm the paramagnetic nature of the prepared nano-particles.

\subsection{Experimental}

This section highlights details of the experiments performed and their procedures. The procedure for the heterogeneous Fenton-process has been described in Sec. 2.3.1. We have worked with various concentration of the catalysts (nano-particles) ranging from 0.1 to $1.0 \mathrm{~g} / \mathrm{L}$ and HP ranging from 5.0 to $9.0 \mathrm{mM}$ (Sec. 3.2) for their optimi- sation. The procedure of the heterogeneous Fenton-process is valid for each concentration of catalyst and oxidant. The determination of the size of the catalysts has been discussed in Sec. 3.1. The optimisation of the catalyst was done by running the reaction for $90 \mathrm{~min}$ and varying its concentration, and keeping other parameters (Conc. of oxidant and dye, pH) constant (Sec. 3.2). Sec. 2.3.2 describes the methods of determination of decolorisation, COD removal efficiency, identification of various ions and intermediate products formed during the treatment and iron content of the catalyst before and after the treatment.

\section{3. 1. Heterogeneous Fenton Procedure}

Stock solutions of $\mathrm{AB}$ and $\mathrm{PX}$ of desired concentration were prepared separately by dissolving in the required amount of Millipore water (Elix3 Century, Millipore India, Bangalore). A mixture of $15 \mathrm{~mL}$ of each of the dyes was adjusted to $100 \mathrm{ml}$ in a volumetric flask.

The concentrations of both the dyes in the mixture were calculated to be $0.15 \mathrm{mM}$ each. The content in the volumetric flask was transferred to a $250 \mathrm{~mL}$ round bottom flask (RB). After adjusting the $\mathrm{pH}$ to the desired value, $4.0 \mathrm{~g} / \mathrm{L} \mathrm{n}-\mathrm{Fe}_{2} \mathrm{O}_{3}$ were added to the mixture. The mixture was stirred for $90 \mathrm{~min}$ when complete equilibrium was established. The equilibrium point was established by measuring the concentration of the dyes from time to time until no change in concentration was observed. The concentration was measured spectrophotometrically using a UV-vis spectrophotometer (HACH, USA; DR 6000) and by following Beer-Lambert law. The reaction was started by adding $0.5 \mathrm{~mL}$ of $\mathrm{HP}$ of desired concentration after equilibration. After centrifuging for $6 \mathrm{~min}$ at $4800 \mathrm{rpm}$ after the selected reaction period, the mixture was used for decolorisation and COD removal studies.

All reactions were carried out in the presence of air and at room temperature (varying between 19 and $25^{\circ} \mathrm{C}$ ). The body and the mouth of the RB were wrapped with aluminium foil to prevent the passage of light. Two holes were pierced through aluminium foil covering the mouth to allow free passage of air. It may be mentioned that the temperature was not controlled during the experiments. Each RB was designated to be sacrificed for analysis after a predetermined time interval. The initial $\mathrm{pH}$ of the solution was adjusted to the desired value with $\mathrm{H}_{2} \mathrm{SO}_{4}$ (the strength ranging between $0.05-0.35 \mathrm{~N}$ depending on the $\mathrm{pH}$ necessary) or $\mathrm{NaOH}$ (the strength ranging between $0.025-0.125$ $\mathrm{N}$ depending on the $\mathrm{pH}$ necessary) using a digital $\mathrm{pH}$ meter (Eutech instrument $\mathrm{pH}$-Tutor). All solutions used in this study were freshly prepared except the dye solution, which was stored at $4{ }^{\circ} \mathrm{C}$ and used within three days.

\section{3. 2. Analytical Methods}

The decolorisation studies were carried out by measuring the absorbance at $539 \mathrm{~nm}$ (for PX) and $604 \mathrm{~nm} \mathrm{(AB}$ 
29) with the help of a UV-vis spectrophotometer $(\mathrm{HACH}$, USA; DR 6000). COD was measured using a COD digester (HACH, USA; DRB 200) and UV-vis spectrophotometer (HACH, USA; DR 6000). HACH, USA, provided the procedure for the determination of COD. ${ }^{2}$

Decolorisation and $\mathrm{COD}_{\text {eff }}$ are calculated according to the following equations:

$$
\begin{gathered}
\text { Decolorisation }(\%)=\frac{A_{0}-A_{t}}{A_{0}} \times 100 \% \\
\mathrm{COD}_{\text {eff }}=\frac{\mathrm{COD}_{0}-\mathrm{COD}_{\mathrm{t}}}{\mathrm{COD}_{0}} \times 100 \%
\end{gathered}
$$

Where the initial absorbance and COD of the solution are $\mathrm{A}_{0}$, and $\mathrm{COD}_{0}$ respectively; the corresponding values at time ' $t$ ' are $A_{t}$, and $\operatorname{COD}_{t}$.

The COD value for the samples containing $\mathrm{H}_{2} \mathrm{O}_{2}$ was corrected quantitatively using Eq. (5), as proposed by Kang et al. ${ }^{22}$ The degradation rate constants in terms of COD removal was determined according to the pseudo-first-order rate laws (Eq. (6)).

$$
\begin{aligned}
& \operatorname{COD}(\mathrm{mg} / \mathrm{L})=\operatorname{COD}_{\mathrm{m}}-\left(0.4706 \cdot\left[\mathrm{H}_{2} \mathrm{O}_{2}\right]-\right. \\
& \left.-4.06 \times 10^{-5} \cdot\left[\mathrm{H}_{2} \mathrm{O}_{2}\right]^{2}\right)
\end{aligned}
$$

Where $\mathrm{COD}_{\mathrm{m}}$ is the measured $\mathrm{COD}(\mathrm{mg} / \mathrm{L})$

$$
-\ln \left(\mathrm{COD} / \mathrm{COD}_{0}\right)=\mathrm{k}_{\mathrm{COD}} \cdot \mathrm{t}
$$

Where, $\mathrm{COD}_{0}$ is the initial COD at time $\mathrm{t}=0$, and $\mathrm{COD}$ is its value at any time $\mathrm{t}(\mathrm{min})$. The first-order rate constant $\left(\mathrm{k}_{\mathrm{COD}}\right)$ for COD removal is the slope of the straight line obtained by plotting $-\ln \left(\mathrm{COD} / \mathrm{COD}_{0}\right)$ vs. time. The kinetics of HP consumption was determined by replacing COD with $\mathrm{HP}$ and $\mathrm{COD}_{0}$ with $\mathrm{HP}_{0}$ in Eq. (6), where $\mathrm{HP}_{0}$ the initial [HP] at time $\mathrm{t}=0$, and $\mathrm{HP}$ is its value at any time $\mathrm{t}(\mathrm{min})$.

Anions, cations, organic acids, phenols and concentration of residual HP were analysed using Ion Chromatography System (ICS) supplied by Thermo Scientific, USA (Dionex, ICS-1100). For anions and organic acids, IonPac AS11 analytical column $(4 \times 250 \mathrm{~mm})$ with a suitable guard column and an automatic electrolytic suppressor (AERS 500, $4 \mathrm{~mm}$ ) was used. The current of the suppressor was maintained at $30 \mathrm{~mA}$ for anions and $38 \mathrm{~mA}$ for organic acids. The mobile phase was $\mathrm{NaOH}(12 \mathrm{mM}$ for anion and $15 \mathrm{mM}$ for organic acids) with a flow rate

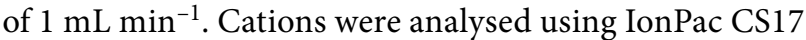
analytical column $(4 \times 250 \mathrm{~mm})$ with a suitable guard column and an automatic electrolytic suppressor (CERS $300,4 \mathrm{~mm}$ ) with a current of $15 \mathrm{~mA}$. The mobile phase was $5 \mathrm{mM} \mathrm{MSA}$ with a flow rate of $1 \mathrm{~mL} \mathrm{~min}^{-1}$. The concentration of residual HP was analysed using CarboPac PA20 analytical column $(3 \times 150 \mathrm{~mm})$ with a suitable guard column and an electrochemical detector (ED 50A).
The mobile phase was $50 \mathrm{mM} \mathrm{NaOH}$ with a flow rate of

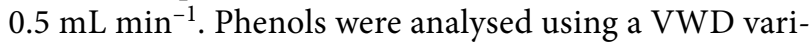
able wavelength absorbance UV-vis detector (cell path length: $10 \mathrm{~mm}$; cell volume: $11 \mu \mathrm{L}$ ). The wavelengths selected for the purpose were $270 \mathrm{~nm}$ and $320 \mathrm{~nm}$. The mobile phase was $0.1 \mathrm{M}$ ammonium acetate solution with a flow rate of $1 \mathrm{~mL} \mathrm{~min}{ }^{-1}$. It was prepared by mixing an appropriate amount of ammonium acetate with a mixture of water and acetonitrile (1:1). All the experiments were repeated at least three times, and the error was always found to be within $\pm 5 \%$. The data presented in the text and figures were analysed by standard deviation using 'Origin 7' (Microcal Inc.) and rounded up to significant values.

The iron content of the catalysts was determined by ICP-OES (ICP-OES: Model No. iCap 7600 Duo, Thermo Fisher). The sample preparation involves solubilising 0.02 $\mathrm{g}$ of the catalyst in $5 \mathrm{~mL}$ conc. $\mathrm{HNO}_{3}$ by heating and evaporating to less than $1 \mathrm{~mL}$. After solubilisation, the samples were diluted to $100 \mathrm{~mL}$ with distilled water and submitted for analysis by ICP-OES. ${ }^{23}$

\section{4. Toxicity Assay}

We have adapted two methods for the toxicity assessment of the treated solutions. The first method is based on the E. coli growth inhibition (metabolic inhibition) bioassay. ${ }^{7,24}$ Luria Bertani (LB) agar, LB broth and ampicillin used in the toxicity assessment study were acquired from Himedia, India. The lyophilised luminescent bacteria, $A$. fischeri used for the toxicity assessment by light loss assay was supplied by Modern Water Inc, USA.

\section{4. 1. Escherichia Coli Growth Inhibition Assay}

The procedure involves dissolving $40 \mathrm{~g}$ of LB agar in $1000 \mathrm{~mL}$ of water followed by autoclaving for $30 \mathrm{~min}$. Upon cooling down to about $40{ }^{\circ} \mathrm{C}$, ampicillin $(1 \mu \mathrm{L}$ for each $\mathrm{mL}$ of LB agar solution) was added, mixed, and aliquots of approximately $10 \mathrm{~mL}$ of the medium were poured into sterilised Petri plates. LB broth $(25 \mathrm{~g})$ was separately dissolved in $1000 \mathrm{~mL}$ of water, aliquoted (9 $\mathrm{mL}$ ) in $100 \mathrm{~mL}$ conical flasks and sterilised by autoclaving for $30 \mathrm{~min}$. Ampicillin $(10 \mu \mathrm{L}), E$. coli culture inocu$\operatorname{lum}(100 \mu \mathrm{L})$ and $1 \mathrm{~mL}$ of the dye or other test solution were added to the sterilised LB broth. The cultures were grown at $37{ }^{\circ} \mathrm{C}$ overnight in a rotary shaker. The following day, the mid-log phase culture was diluted 10,000 times, and $10 \mu \mathrm{L}$ of the diluted culture was spread over the LB agar plates prepared earlier. The plates were incubated for $16 \mathrm{~h}$ in a $37^{\circ} \mathrm{C}$ incubator as described earlier. ${ }^{25}$ Colony forming units (CFUs) formed in each plate was counted. All steps of the experiment were performed under sterilized conditions. The relative toxicities of the treated solutions, measured as reduction in CFU, were with respect to the control. 


\section{4. 2. Alivibrio fischeri Luminescent Assay}

In this method, the toxicity was measured using a Microtox FX test system (Modern Water Inc, USA). This method is based on the principles suggested by ISO (2007). ${ }^{26}$ The relative toxicity of each sample was measured using an $81.9 \%$ screening test, the procedure of which was supplied by Modern Water Inc, USA. The assay was conducted at $15-22{ }^{\circ} \mathrm{C}$ by adding an osmotic adjusting solution (OAS) containing $22 \% \mathrm{NaCl}$. The test is called the $81.9 \%$ screening test, as all the samples are diluted at $81.9 \%$ of the initial sample concentration by adding a $22 \% \mathrm{NaCl}$ solution. ${ }^{27}$ The purpose of using $22 \% \mathrm{NaCl}$ in OAS is to bring the salinity of the samples to approximately $2 \%$ to allow the regular cellular activity of $A$. fischeri and emission of luminescence (Sourced from "Microtox FX analyser user manual supplied by Modern Water Inc, USA"). The inhibition of luminescence or light loss (\%) by the bacterium was analysed by the Microtox FX photometer. The light loss (\%) was used as a measure of the relative toxicity of the samples.

\section{Results and Discussion}

As already discussed, not adequate information has been documented in the literature on the removal of mixture of dyes by AOPs. In this section, the removal of mixture of two dyes ( $\mathrm{AB}$ and $\mathrm{PX})$ by heterogeneous Fenton process has been discussed. Reduction in COD has been taken as an indication of removal of dyes. The critical step in the removal process lies in the ability of both nano and micro iron (III) oxide particles to decompose HP and SPS producing hydroxyl and sulphate radicals. To maximize the COD removal, we have first optimized various parameters such as catalyst load, concentration of oxidant, $\mathrm{pH}$ in $\mathrm{n}-\mathrm{Fe}_{2} \mathrm{O}_{3} / \mathrm{HP}$ system. These optimized parameters were used for other systems as well. Further studies such as (i) COD removal and its dependency on particle size, (ii) reusability of catalysts, (iii) kinetics of COD removal and HP consumption, (iv) product identification, and (v) toxicity assessment were also carried out under the same optimized conditions.

\section{1. Characterisation of $n-\mathrm{Fe}_{2} \mathrm{O}_{3}$ Catalyst}

The nano-particles were characterised by FTIR, TEM, EDS, powder XRD and VSM. The FTIR spectrum of the $n-\mathrm{Fe}_{2} \mathrm{O}_{3}$ particles are shown in Fig. 2. The peak at 604

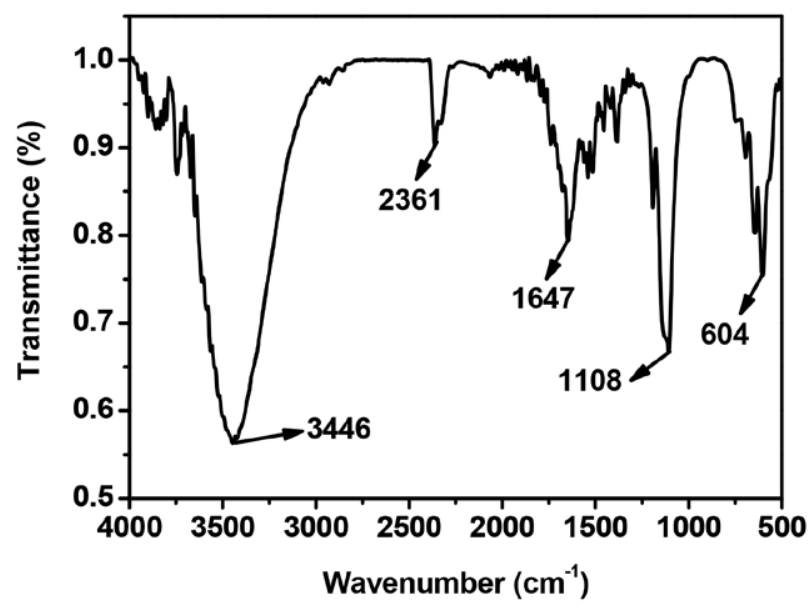

Figure 2. FTIR spectrum of $n-\mathrm{Fe}_{2} \mathrm{O}_{3}$ particles.

$\mathrm{cm}^{-1}$ is assigned to $\mathrm{Fe}-\mathrm{O}$ stretching band indicating the presence of $\mathrm{Fe}_{2} \mathrm{O}_{3}$, that at $3446 \mathrm{~cm}^{-1}$ to the characteristic stretching vibrations of $-\mathrm{OH}$ moieties probably belonging to the adsorbed water molecules on the surface during the preparation process of the catalyst and that at $1647 \mathrm{~cm}^{-1}$ to $\mathrm{H}-\mathrm{OH}$ bending vibrations at $\gamma-\mathrm{Fe}_{2} \mathrm{O}_{3}$ surface. ${ }^{28-30}$ The weight (\%) of iron and oxygen on the surface of $n-\mathrm{Fe}_{2} \mathrm{O}_{3}$ as analysed by EDX, was found to be 83.71 and $16.29 \%$, respectively (Fig. 3).

The morphology of the nano-particles particle size distribution, powder XRD and VSM are shown in Fig. 4. It is observed that the shape of the particles is spherical (Fig.

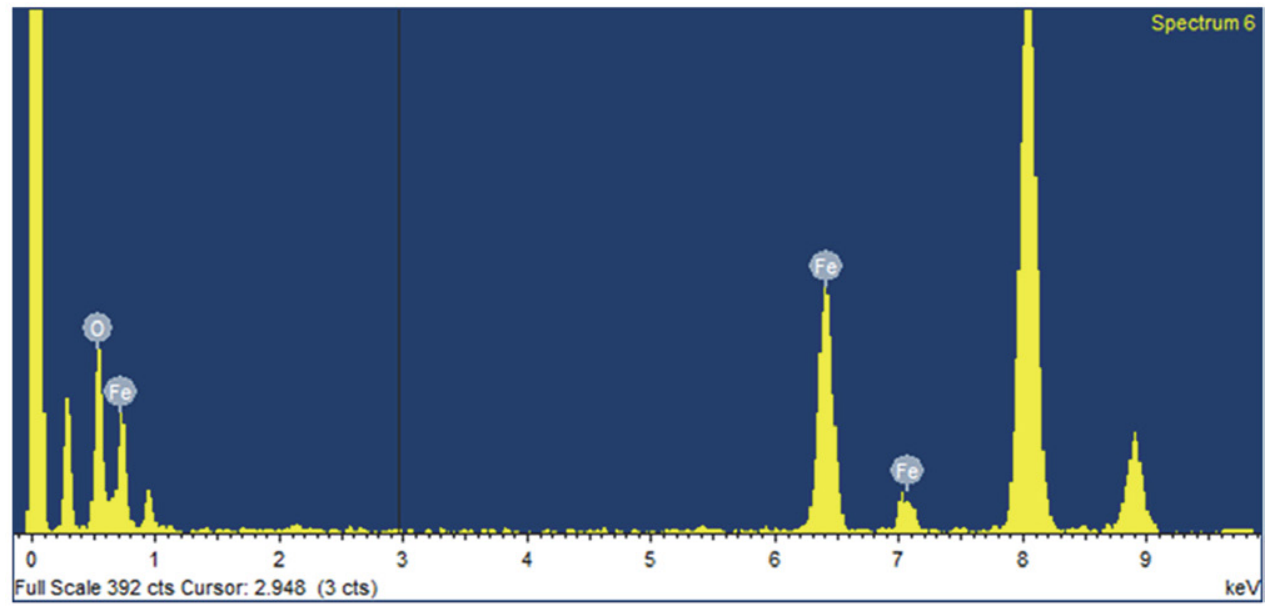

Figure 3. $\mathrm{EDX}$ analysis of $\mathrm{n}-\mathrm{Fe}_{2} \mathrm{O}_{3}$ particles. 

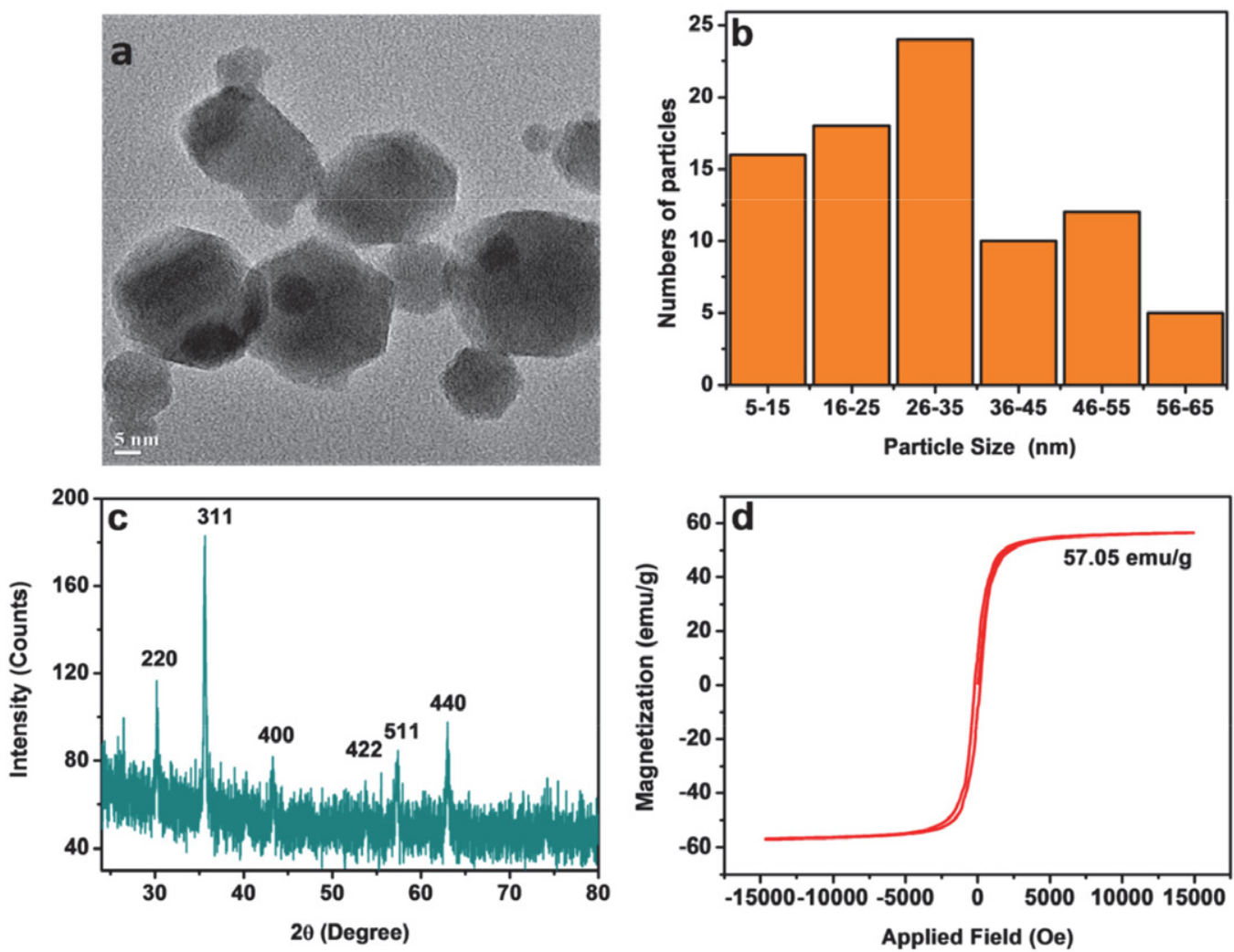

Figure 4. Characterisation of $\mathrm{n}-\mathrm{Fe}_{2} \mathrm{O}_{3}$ particles: a. TEM image; b. Particle size distribution; c. XRD diffractogram; d. Magnetisation curve.

4a). The size range of the particles calculated using image $j$ software was found to vary from 5-65 $\mathrm{nm}$, and the average particle size lies within $26-35 \mathrm{~nm}$ (Fig. 4b). The XRD diffractogram shows diffraction peaks at angles $2 \theta=30.22^{\circ}$, $35.64^{\circ}, 43.25^{\circ}, 53.75^{\circ}, 57.45^{\circ}$, and $62.98^{\circ}$ which correspond to the 220, 311, 400,422, 511, 440 planes of $\mathrm{Fe}_{2} \mathrm{O}_{3}$ NPs (Fig. 4c). ${ }^{24,31,32}$ The XRD data suggests that the $\mathrm{Fe}_{2} \mathrm{O}_{3}$ particles are $\gamma-\mathrm{Fe}_{2} \mathrm{O}_{3} \cdot{ }^{30}$ The VSM analysis shows that the nano-catalysts possessed super paramagnetic property with a saturation magnetisation of $57.05 \mathrm{emu} / \mathrm{g}$ (Fig. 4d).

\section{2. Optimisation of Operational Parameters for $\mathrm{n}-\mathrm{Fe}_{2} \mathrm{O}_{3}$ /oxidant Systems}

The optimization of catalyst load in $\mathrm{n}-\mathrm{Fe}_{2} \mathrm{O}_{3}$ /oxidant systems was initially done on the basis of decolorisation efficiency. The concentration of the nano-particles was increased from 0.1 to $1.0 \mathrm{~g} / \mathrm{L}$ keeping other parameters constant: $[\mathrm{HP}]=[\mathrm{SPS}]=7.0 \mathrm{mM} ;[\mathrm{AB}]=[\mathrm{PX}]=0.15 \mathrm{mM} ; \mathrm{pH}$ $=3$; treatment period $=90 \mathrm{~min}$. While decolorisation remained practically constant $(95.0$ and $91.4 \%$ for $\mathrm{AB}$ and $\mathrm{PX}$, respectively) from $0.4 \mathrm{~g} / \mathrm{L}$ onwards for the systems n- $\mathrm{Fe}_{2} \mathrm{O}_{3} / \mathrm{HP}$, maximum decolorisation ( 97.0 and $91.4 \%$ for $\mathrm{AB}$ and $\mathrm{PX}$, respectively) was observed at $0.6 \mathrm{~g} / \mathrm{L}$ in n- $\mathrm{Fe}_{2} \mathrm{O}_{3} /$ SPS system (Table 1 ).

The effect of $\mathrm{pH}$ on decolorisation at the optimum load of the nano-particles $(0.4 \mathrm{~g} / \mathrm{L})$ was also considered. It was found that decolorisation was highest at $\mathrm{pH} 3(95.0$ and $91.4 \%$ for $\mathrm{AB}$ and $\mathrm{PX}$, respectively) and nil at $\mathrm{pH} \geq 5.9$ (the natural $\mathrm{pH}$ of the mixture of dyes). The higher efficiency at $\mathrm{pH} 3$ may be due to the higher oxidation potential of $\mathrm{HO}$ radicals, leaching of more iron species into the solution and forming catalyst-pollutant inner-sphere complexes. ${ }^{33-35}$ The higher decolorisation efficiency at lower $\mathrm{pH}$ and lower at higher $\mathrm{pH}$ may also be attributed to the surface properties of the catalyst. It is known that degradation in heterogeneous catalysis takes place at the catalyst's surface, the adsorption of the target molecule on its surface plays a vital role in the degradation process. The adsorption depends on the charge on the target molecule and surface of the catalyst. The point of zero charge (PZC) of a catalyst is the $\mathrm{pH}$ at which the surface is neutral. Therefore, the surface is acidic at $\mathrm{pH}<\mathrm{PZC}$ and basic at $\mathrm{pH}>\mathrm{PZC}$. Since, $\mathrm{AB}$ and $\mathrm{PX}$ are anionic dyes, they are attracted towards the surface at $\mathrm{pH}<\mathrm{PZC}$. In the case of $\mathrm{n}-\mathrm{Fe}_{2} \mathrm{O}_{3}$, the PZC lies between 6.0 and 6.8, and therefore, $\mathrm{AB}$ and $\mathrm{PX}$ are attracted towards the surface at $\mathrm{pH}<6$, i.e. in acidic $\mathrm{pH} .{ }^{36,16}$ Since there is no adsorption of the dyes on the catalyst at $\mathrm{pH}>6$, no decolorisation was observed at $\mathrm{pH} \geq$ 5.9. The reduced decolorisation at higher $\mathrm{pH}$ may also be attributed to the oxidation of $\mathrm{NaOH}$ by $\mathrm{HP}$ (Eq. (7)). ${ }^{37}$

$$
2 \mathrm{NaOH}+\mathrm{H}_{2} \mathrm{O}_{2}+6 \mathrm{H}_{2} \mathrm{O} \rightarrow \mathrm{Na}_{2} \mathrm{O}_{2} \cdot 8 \mathrm{H}_{2} \mathrm{O}
$$

The effect of $\mathrm{pH}$ on decolorisation in $\mathrm{n}-\mathrm{Fe}_{2} \mathrm{O}_{3} / \mathrm{SPS}$ system was established by carrying out the reaction at $\mathrm{pH}$ 
3.0, 5.9, 9.0 and 11.0. Table 1 shows that significant decolorisation was achieved within a wide range of $\mathrm{pH}$ values, although maximum decolorisation was achieved only at pH 3.

The optimization of HP was done by varying its concentration from 5.0 to $9.0 \mathrm{mM}$ while keeping other parameters constant $\left([\mathrm{AB}]=[\mathrm{PX}]=0.15 \mathrm{mM} ; \mathrm{pH}=3 ;\left[\mathrm{n}-\mathrm{Fe}_{2} \mathrm{O}_{3}\right]\right.$ $=0.4 \mathrm{~g} / \mathrm{L})$. The decolorisation concerning both the components of the dye solution was found to increase up to 7.0 $\mathrm{mM}$, beyond which a slight decrease was observed (Table 1). A similar result was also obtained in $\mathrm{n}-\mathrm{Fe}_{2} \mathrm{O}_{3} / \mathrm{SPS}$ system. The initial increase in decolorisation with $\mathrm{HP}$ was due to the higher generation of hydroxyl radicals and decrease at higher conc. is due to the self-scavenging of hydroxyl radicals as well as by HP (Eqs. (8) and (9)). ${ }^{37}$ Apart from being less reactive than $\mathrm{HO}^{\prime}$, the resulting hydroperoxyl radicals $\left(\mathrm{HO}_{2}{ }^{\circ}\right)$ further reduce the availability of $\mathrm{HO}^{\circ}$ (Eq. (10)), a factor which is responsible for a lower degree of decolorisation. ${ }^{38}$

$$
\begin{aligned}
& \mathrm{HO}^{\bullet}+\mathrm{HO}^{\bullet} \rightarrow \mathrm{H}_{2} \mathrm{O}_{2} \\
& \mathrm{H}_{2} \mathrm{O}_{2}+\mathrm{HO}^{\bullet} \rightarrow \mathrm{HO}_{2}^{\bullet}+\mathrm{H}_{2} \mathrm{O} \\
& \mathrm{HO}_{2}^{\cdot}+\mathrm{HO}^{\bullet} \rightarrow \mathrm{H}_{2} \mathrm{O}+\mathrm{O}_{2}
\end{aligned}
$$

Going by the discussion above, the optimum parameters for decolorisation in $\mathrm{n}-\mathrm{Fe}_{2} \mathrm{O}_{3}$ /oxidant systems may be summarized as: $[\mathrm{AB}]=[\mathrm{PX}]=0.15 \mathrm{mM} ; \mathrm{pH}=3 ;\left[\mathrm{n}-\mathrm{Fe}_{2} \mathrm{O}_{3}\right]$ $=0.4 \mathrm{~g} / \mathrm{L}$ (for HP system) and $0.6 \mathrm{~g} / \mathrm{L}$ (for SPS system), $[\mathrm{HP}]=[\mathrm{SPS}]=7.0 \mathrm{mM}$. A comparison of decolorisation in both the systems shows that they possess equal efficiency at their optimum parameters even though a higher concentration of catalyst is required for SPS system than for HP.

\section{3. COD removal Studies at Optimum Parameters for $\mathrm{n}-\mathrm{Fe}_{2} \mathrm{O}_{3} / \mathrm{HP}$ and $\mathrm{n}-\mathrm{Fe}_{2} \mathrm{O}_{3} /$ SPS Systems}

As it is known that HP interference results in the over estimation of COD values, ${ }^{22}$ we have calculated the actual
COD values at optimum parameters by eliminating the interference due to HP. The COD values presented in the text are inclusive of the HP factor (represented as m-COD) unless otherwise stated. Nevertheless, the result gives a qualitative idea about the COD value, which would obviously be higher than the value obtained after eliminating the HP factor.

In order to find $\mathrm{COD}_{\text {eff }}$ of both the systems at their respective optimal parameters, we have varied the treatment period up to $300 \mathrm{~min}$. To our surprise, the $\mathrm{COD}_{\text {eff }}$ was found to be very low (1.4 and 6.8\% respectively for HP and SPS systems) at $300 \mathrm{~min}$ of reaction even though complete decolorisation was achieved under the present conditions. So, it was decided to increase the catalyst load further to see if there is an increase in $\mathrm{COD}_{\text {eff. The reaction }}$ with catalyst load varying from 1.0 to $6.0 \mathrm{~g} / \mathrm{L}$ was carried out under optimum parameters, i.e. $[\mathrm{HP}]=7.0 \mathrm{mM}$; treatment period $=300 \mathrm{~min}:[\mathrm{AB}]=[\mathrm{PX}]=0.15 \mathrm{mM} ; \mathrm{pH}=3$; equilibrium period $=90 \mathrm{~min}$. Although complete decolorisation was obtained from $0.4 \mathrm{~g} / \mathrm{L}$ onwards, an increase in $\mathrm{m}-\mathrm{COD}_{\text {eff }}$ from $45.6 \%$ to $72.1 \%$ at $300 \mathrm{~min}$ was observed when the load was increased from 1.0 to $4.0 \mathrm{~g} / \mathrm{L}$. A slight decrease in the value was observed when the load was increased to $6.0 \mathrm{~g} / \mathrm{L}$ (Fig. 5). Thus, $4.0 \mathrm{~g} / \mathrm{L}$ was taken as the optimum concentration of $\mathrm{n}-\mathrm{Fe}_{2} \mathrm{O}_{3}$ throughout the study. This initial increase in $\mathrm{m}-\mathrm{COD}_{\text {eff }}$ may be attributed to the acceleration of iron leaching and HP activation generating more $\mathrm{HO}^{\circ}$ radicals due to an increase in the number of active sites on the catalyst surface area available for degradation. The decrease at higher catalyst concentration may be due to the agglomeration of nano-particles. Another reason may be due to the scavenging of $\mathrm{HO}^{\circ}$ and $\mathrm{HO}_{2}{ }_{2}$ (Eq. (9) radicals on the oxide surface (Eqs. (11) - (13)). ${ }^{39-42}$ As already discussed earlier, the presence of HP in the solution results in the over estimation of COD. Hence, there is a need to eliminate the interference due to HP.

$$
\begin{aligned}
& \equiv \mathrm{Fe}^{2+}+\mathrm{HO}^{\bullet} \rightarrow \equiv \mathrm{Fe}^{3+}+\mathrm{HO}^{-} \\
& \equiv \mathrm{Fe}^{2+}+\mathrm{HO}_{2}^{\circ} \rightarrow \equiv \mathrm{Fe}^{3+}+\mathrm{HOO}^{-} \\
& \equiv \mathrm{Fe}^{3+}+\mathrm{HO}_{2}^{\cdot} \rightarrow \equiv \mathrm{Fe}^{2+}+\mathrm{H}^{+}+\mathrm{O}_{2}
\end{aligned}
$$

\begin{tabular}{|c|c|c|c|c|c|c|c|c|c|c|c|c|c|c|}
\hline \multirow{4}{*}{$\begin{array}{l}{\left[\mathrm{n}-\mathrm{Fe}_{2} \mathrm{O}_{3}\right]} \\
(\mathrm{g} / \mathrm{L})\end{array}$} & \multicolumn{4}{|c|}{ Catalyst } & \multicolumn{6}{|c|}{ Oxidant } & \multicolumn{4}{|c|}{$\mathrm{pH}$} \\
\hline & \multicolumn{4}{|c|}{ Decolorization (\%) } & \multirow{3}{*}{$\begin{array}{l}\text { [Oxidant }] \\
(\mathrm{mM})\end{array}$} & \multicolumn{4}{|c|}{ Decolorization (\%) } & \multirow[t]{3}{*}{$\mathrm{pH}$} & \multicolumn{4}{|c|}{ Decolorization (\%) } \\
\hline & \multicolumn{2}{|c|}{$\begin{array}{c}\text { n-Fe } \mathrm{Fe}_{2} \mathrm{O}_{3} / \\
\mathrm{HP} \text { system }\end{array}$} & \multicolumn{2}{|c|}{$\begin{array}{c}\text { n-Fe } \mathrm{Fe}_{2} \mathrm{O}_{3} / \\
\text { SPS system }\end{array}$} & & \multicolumn{2}{|c|}{$\begin{array}{c}\text { n-Fe }{ }_{2} \mathrm{O}_{3} / \\
\mathrm{HP} \text { system }\end{array}$} & \multicolumn{2}{|c|}{$\begin{array}{c}\text { n- } \mathrm{Fe}_{2} \mathrm{O}_{3} / \\
\text { SPS system }\end{array}$} & & \multicolumn{2}{|c|}{$\begin{array}{c}\mathrm{n}-\mathrm{Fe}_{2} \mathrm{O}_{3} / \\
\mathrm{HP} \text { system }\end{array}$} & \multicolumn{2}{|c|}{$\begin{array}{c}\text { n-Fe }{ }_{2} \mathrm{O}_{3} / \\
\text { SPS system }\end{array}$} \\
\hline & $\mathrm{AB}$ & PX & $\mathbf{A B}$ & PX & & $\mathrm{AB}$ & PX & $\mathrm{AB}$ & PX & & $\mathrm{AB}$ & PX & $\mathbf{A B}$ & PX \\
\hline 0.1 & 62.0 & 51.7 & 39.9 & 15.8 & 5.0 & 66.1 & 54.3 & 94.3 & 79.7 & 3.0 & 95.0 & 91.4 & 97.0 & 91.4 \\
\hline 0.2 & 82.4 & 72.0 & 47.1 & 23.1 & 6.0 & 86.1 & 84.4 & 96.5 & 89.2 & 5.9 & No & & 95.4 & 84.5 \\
\hline 0.4 & 95.0 & 91.4 & 88.2 & 64.3 & 7.0 & 95.0 & 91.4 & 97.0 & 91.4 & - & deco & risation & - & - \\
\hline 0.6 & 95.2 & 91.0 & 97.0 & 91.4 & 8.0 & 93.4 & 90.0 & 93.8 & 85.5 & 9.0 & was & & 94.2 & 82.8 \\
\hline 0.8 & 94.2 & 91.0 & 92.2 & 72.9 & 9.0 & 91.2 & 85.9 & 93.0 & 76.9 & 11.0 & obse & & 25.6 & 03.0 \\
\hline 1.0 & 95.2 & 91.4 & 89.5 & 66.4 & - & - & - & - & - & - & - & - & - & - \\
\hline
\end{tabular}

Table. 1. Optimization of operational parameters of mixture of dyes for $n-\mathrm{Fe}_{2} \mathrm{O}_{3} / \mathrm{HP}$ and $\mathrm{n}-\mathrm{Fe}_{2} \mathrm{O}_{3} / \mathrm{SPS}$ systems: $[\mathrm{AB}]=[\mathrm{PX}]=0.15 \mathrm{mM} ;\left[\mathrm{n}-\mathrm{Fe} \mathrm{O}_{3}\right]$ $=0.4 \mathrm{~g} / \mathrm{L} ;\left[\mathrm{n}-\mathrm{Fe}_{2} \mathrm{O}_{3}\right]=0.6 \mathrm{~g} / \mathrm{L} ;[\mathrm{HP}]=[\mathrm{SPS}]=7.0 \mathrm{mM} ; \mathrm{pH}=3$; treatment period $=90 \mathrm{~min}$. 


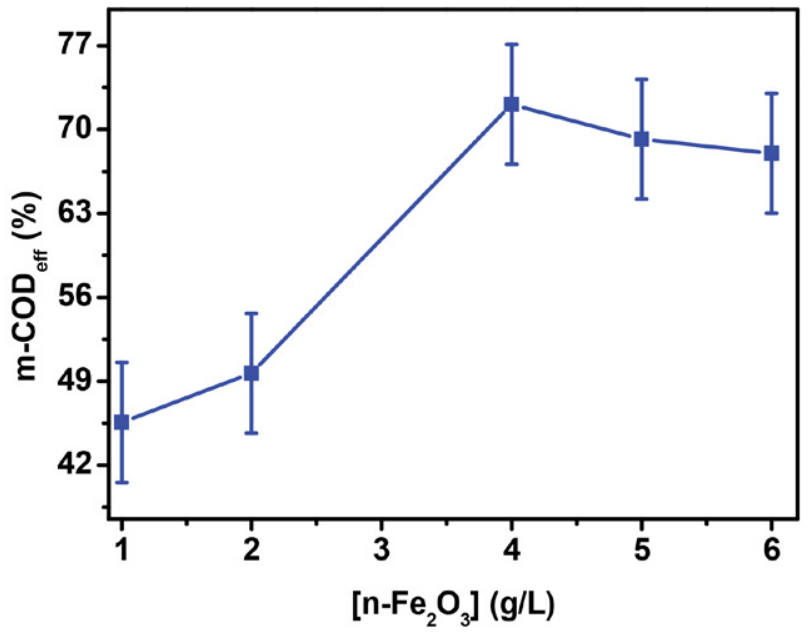

Figure 5. Effect of catalyst load on the $\mathrm{m}-\mathrm{COD}_{\text {eff }}$ of mixture of dyes $(\mathrm{AB}+\mathrm{PX}):[\mathrm{HP}]=7.0 \mathrm{mM} ; \mathrm{AB}]=[\mathrm{PX}]=0.15 \mathrm{mM} ; \mathrm{pH}=3$; equilibrium period $=90 \mathrm{~min}$; treatment period $=300 \mathrm{~min}$.

To see the increase in $\mathrm{m}-\mathrm{COD}_{\text {eff }}$ pattern with time, we have carried out the reaction from 10 to $360 \mathrm{~min}$. Table 2 summaries the effect of HP on the $\mathrm{m}-\mathrm{COD}_{\text {eff }}$ of the process. It is thus apparent that the presence of $\mathrm{HP}$ leads to a reduction of $\mathrm{m}-\mathrm{COD}_{\text {eff }}$ values. Therefore, our result is in good agreement with the findings of Kang et al. ${ }^{22}$. It is apparent from Table 2 that the COD removal process takes place in two stages - a slow induction period ( $1^{\text {st }}$ stage) followed by a fast degradation process $\left(2^{\text {nd }}\right.$ stage). During the induction period, which lasted up to $60 \mathrm{~min}$, the $\mathrm{COD}_{\text {eff }}$ practically remained constant (31.3\% in $10 \mathrm{~min}$ to $35.7 \%$ in $60 \mathrm{~min}$ ), beyond which an increase was observed, and the value reached $83.8 \%$ in $360 \mathrm{~min}$. This is also evident from the consumption of $\mathrm{HP}$, which follows the same trend as $\mathrm{COD}_{\text {eff }}$ (Table 2). On the other hand, complete decolorisation was achieved at $120 \mathrm{~min}$ of the reaction. From Table 2, it is evident that $67.2 \%$ of HP is consumed in 60 min with a corresponding $\mathrm{COD}_{\text {eff }}$ of $35.7 \%$. On the other hand, rest of the HP was consumed in the next $300 \mathrm{~min}$ for an additional $48.1 \% \mathrm{COD}_{\text {eff. }}$ Therefore, the HP, which is consumed rapidly up to $60 \mathrm{~min}$, mainly was used towards the decolorisation.

Previous studies have suggested that iron leaching from the surface of $n-\mathrm{Fe}_{2} \mathrm{O}_{3}$ into the solution forms the rate determining step of this reaction ${ }^{43,44}$ and therefore, the slow leaching of iron takes place in the first stage, i.e. induction period. It appears that during the induction period sufficient amount of $\mathrm{HO}^{\circ}$ radicals are not formed through the activation of HP by $\mathrm{n}-\mathrm{Fe}_{2} \mathrm{O}_{3}$. Further, part of the $\mathrm{HO}^{\circ}$ radicals might be recombined or scavenged quickly in the presence of high conc. of HP (Eqs. (8) and (9)) and sizeable active surface (Eq. (11)) and partly might be engaged to a great extent in breaking the $\mathrm{N}=\mathrm{N}$ bond leading to decolorisation and a lesser extent in removing the dyes and intermediate products and hence COD. The second and fast process primarily involves the interaction of $\mathrm{HO}^{\circ}$ radicals, generated through the activation of $\mathrm{HP}$ with dissolved iron $\left(\mathrm{Fe}^{2+}\right)$ (Eq. (4)), with the dyes leading to their degradation. The $\mathrm{HO}^{\circ}$ radicals generated during the process are involved in the colour and COD removal process by acting in two different ways: by attacking the $-\mathrm{N}=\mathrm{N}-$ chromophore or the carbon attached to the azo bond. ${ }^{45,46}$ In both cases, the dye molecules are fragmented, causing colour and COD removal.

Heterogeneous Fenton-type reactions $\left(\mathrm{n}-\mathrm{Fe}_{2} \mathrm{O}_{3} /\right.$ SPS) were carried out with $4.0 \mathrm{~g} / \mathrm{L}$ of $\mathrm{Fe}_{2} \mathrm{O}_{3}$ in the presence of SPS as an oxidant. To study the effect of the equimolar concentration of oxidants, we have considered the concentration of SPS as $7.0 \mathrm{mM}$. The other parameters taken were same as with heterogeneous Fenton process, e.g. $[\mathrm{AB}]=[\mathrm{PX}]=0.15 \mathrm{mM} ; \mathrm{pH}=3$, equilibrium period $=90 \mathrm{~min}$. Under these operational parameters, $\mathrm{COD}_{\text {eff }}$ was found to be only $28.5 \%$ in 360 min. The effect of $\mathrm{pH}$ was also studied on this system, and it was observed that $\mathrm{COD}_{\text {eff }}$ was highest at $\mathrm{pH} 3$ and negligible at other $\mathrm{pHs}$.

Table 2. COD removal efficiency of mixture of dyes $(\mathrm{AB}+\mathrm{PX}):[\mathrm{AB}]=[\mathrm{PX}]=0.15 \mathrm{mM}$; $\left[\mathrm{n}-\mathrm{Fe}_{2} \mathrm{O}_{3}\right]=4.0 \mathrm{~g} / \mathrm{L} ;[\mathrm{HP}]=7.0 \mathrm{mM} ; \mathrm{pH}=3$; equilibrium period $=90 \mathrm{~min}$.

\begin{tabular}{|c|c|c|c|c|c|}
\hline \multirow{2}{*}{$\begin{array}{l}\text { Treatment } \\
\text { period } \\
\text { (Min) }\end{array}$} & \multicolumn{2}{|c|}{$\begin{array}{c}\text { Decolorisation } \\
(\%)\end{array}$} & \multirow[t]{2}{*}{$\begin{array}{c}\text { Consumption } \\
\text { of }[\mathrm{HP}](\%)\end{array}$} & \multirow[t]{2}{*}{$\begin{array}{c}\mathrm{m}-\mathrm{COD}_{\mathrm{eff}} \\
(\%)\end{array}$} & \multirow[t]{2}{*}{$\begin{array}{c}\mathrm{COD}_{\text {eff }} \\
(\%)\end{array}$} \\
\hline & $\mathrm{AB}$ & PX & & & \\
\hline 10 & 71.6 & 65.3 & 64.0 & 4.1 & 31.3 \\
\hline 30 & 83.6 & 77.6 & 64.0 & 6.1 & 33.2 \\
\hline 60 & 97.9 & 96.9 & 67.2 & 10.9 & 35.7 \\
\hline 120 & 100.0 & 100.0 & 76.3 & 29.3 & 45.1 \\
\hline 180 & 100.0 & 100.0 & 87.3 & 47.4 & 58.8 \\
\hline 240 & 100.0 & 100.0 & 95.4 & 55.7 & 74.9 \\
\hline 300 & 100.0 & 100.0 & 98.9 & 72.1 & 83.1 \\
\hline 360 & 100.0 & 100.0 & 99.8 & 78.2 & 83.8 \\
\hline
\end{tabular}

$\mathrm{m}-\mathrm{COD}_{\text {eff }}-\mathrm{COD}$ removal efficiency in the presence of residual HP

$\mathrm{COD}_{\text {eff }}-\mathrm{COD}$ removal efficiency in the absence of residual HP 


\section{4. Effect of Particle Size on $\mathrm{COD}_{\text {eff }}$ of the Mixture of Dyes}

To establish the effect of particle size of $\mathrm{Fe}_{2} \mathrm{O}_{3}$ particles on the $\mathrm{COD}_{\text {eff }}$, we have used particles of two different sizes. The effect of $n-\mathrm{Fe}_{2} \mathrm{O}_{3}$ has already been described in the earlier section. The other iron oxide used in this work is $\mathrm{m}-\mathrm{Fe}_{2} \mathrm{O}_{3}$ particles with particle size $<5 \mu \mathrm{m}$. The oxidants used in this reaction were HP and SPS. The operational parameters used in $n-\mathrm{Fe}_{2} \mathrm{O}_{3} / \mathrm{HP}$ system as described in Sec. 3.3 was also employed in this reaction $\left(\left[\mathrm{m}-\mathrm{Fe}_{2} \mathrm{O}_{3}\right]=\right.$ $4.0 \mathrm{~g} / \mathrm{L} ;$ [Oxidant $]=7.0 \mathrm{mM} ; \mathrm{AB}]=[\mathrm{PX}]=0.15 \mathrm{mM} ; \mathrm{pH}$ $=3$; equilibrium period $=90 \mathrm{~min}) . \mathrm{m}-\mathrm{COD}_{\text {eff }}$ with a value of $51 \%$ in $360 \mathrm{~min}$ in the presence of HP, was completely inhibited in the presence of SPS. It may be noted that under similar conditions, $\mathrm{m}-\mathrm{COD}_{\text {eff }}$ was $78.2 \%$ in $\mathrm{n}-\mathrm{Fe}_{2} \mathrm{O}_{3} /$ HP system. A comparison of the effectiveness of all the systems at their optimum parameters is shown in Fig. 6. It is apparent from the figure that SPS inhibits $\mathrm{m}-\mathrm{COD}_{\text {eff }}$ in both the systems (n- $-\mathrm{Fe}_{2} \mathrm{O}_{3}$ and $\mathrm{m}-\mathrm{Fe}_{2} \mathrm{O}_{3}$ ), more so in $\mathrm{m}-\mathrm{Fe}_{2} \mathrm{O}_{3}$ than $\mathrm{n}-\mathrm{Fe}_{2} \mathrm{O}_{3}$. Hence, study with the only $\mathrm{n}-\mathrm{Fe}_{2} \mathrm{O}_{3}$ system was considered further.

\section{5. Reusability of $\mathrm{n}-\mathrm{Fe}_{2} \mathrm{O}_{3}$ in Heterogeneous Fenton Reaction}

The economy of the heterogeneous Fenton process lies in the stability and reusability of the catalyst in multiple cycles. After each cycle of reaction under optimum parameters, the catalysts were separated from the solution with the help of a vacuum pump. The particles were then washed with $500 \mathrm{~mL}$ water followed by $250 \mathrm{~mL}$ methanol repeatedly until the solution's $\mathrm{pH}$ after washing was maintained at 7. In the end, the particles were washed with 1000 $\mathrm{mL}$ water to make them free of methanol. The particles were dried in an oven for 8 hours, cooled at room temperature, grinded and stored for the following reaction cycle. Four cycles of reaction were performed, and the result is presented in Fig. 6. It is observed that the $m-\mathrm{COD}_{\text {eff }}$ remains constant until the $2^{\text {nd }}$ cycle, after which a rapid decrease in efficiency was observed, and the value reached $11.6 \%$ in the $4^{\text {th }}$ cycle. The lower efficiency from the $3^{\text {rd }}$ cycle onwards may be attributed to diverse factors such as lower leaching of iron, resulting in a lower contribution to homogeneous Fenton process, catalyst surface area reduction due to aggregation, and deactivation of active sites by adsorption of organic intermediates etc. ${ }^{35,39,47}$ The nano-particles lose their colloidal stability due to dipole-dipole interaction, causing them to agglomerate. ${ }^{48}$ As seen in Fig. 7, the number of black spots increases in each cycle, indicating the occurrence of agglomeration. As the number of agglomeration increases with the treatment period, a decrease in the number of nano-particles and hence surface area is observed. This explains a reduction in $\mathrm{m}-\mathrm{CO}$ $\mathrm{D}_{\text {eff }}$ in successive cycles. Nevertheless, complete decolorisation was achieved in all the cycles. To verify the amount of iron leaching from $\mathrm{n}-\mathrm{Fe}_{2} \mathrm{O}_{3}$, the samples at the end of each of the four cycles were analysed by ICP-OES and was found to be $8.3,41.1,42.3$, and $50.1 \%$, respectively.

\section{6. Kinetics of COD Removal and HP Consumption in $\mathrm{n}-\mathrm{Fe}_{2} \mathrm{O}_{3} / \mathrm{HP}$ System}

As discussed before, the COD removal process consists of a slow and a fast process. Both the processes have been shown to follow pseudo-first-order kinetics (Fig. 8). The slow process takes place within the first $60 \mathrm{~min}$ of the reaction with a rate constant of 1.49 and $1.32\left(10^{-3} \mathrm{~min}^{-1}\right)$ from 0-60 min with and without HP interference respectively, and the corresponding values of the faster process from $120-300 \mathrm{~min}$ are 7.94 and $6.73\left(10^{-3} \mathrm{~min}^{-1}\right)$ respectively (Table 3 ). Data beyond $300 \mathrm{~min}$ was not considered for kinetic study as no appreciable change in $\mathrm{COD}_{\text {eff }}$ value was observed, and the reaction appeared to have completed with $\approx 99 \%$ consumption of HP (Table 2 ). The higher rate constant with HP interference compared to that with-
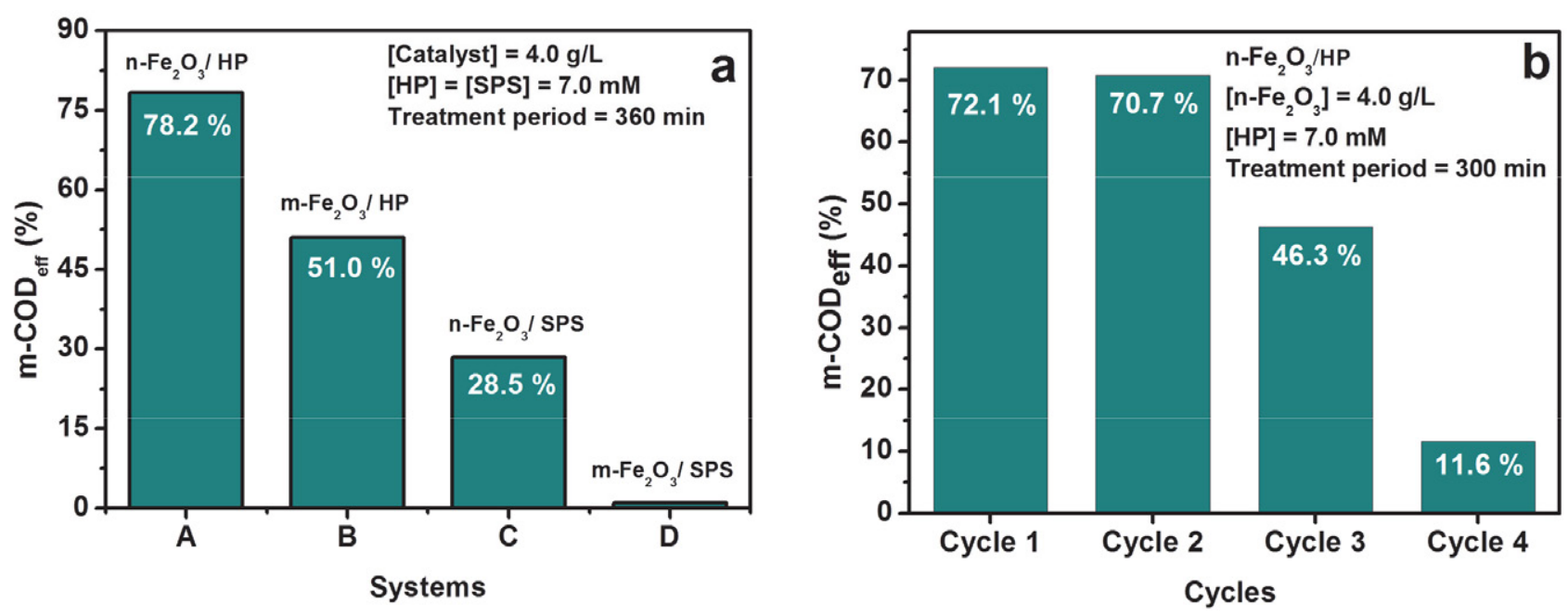

Figure 6. Effect of particle size of catalyst on $\mathrm{m}-\mathrm{COD}_{\text {eff }}(\mathrm{a})$ and reusability of catalyst $(\mathrm{b}):[\mathrm{AB}]=[\mathrm{PX}]=0.15 \mathrm{mM}$; equilibrium period $=90 \mathrm{~min} ; \mathrm{pH}=3$. 

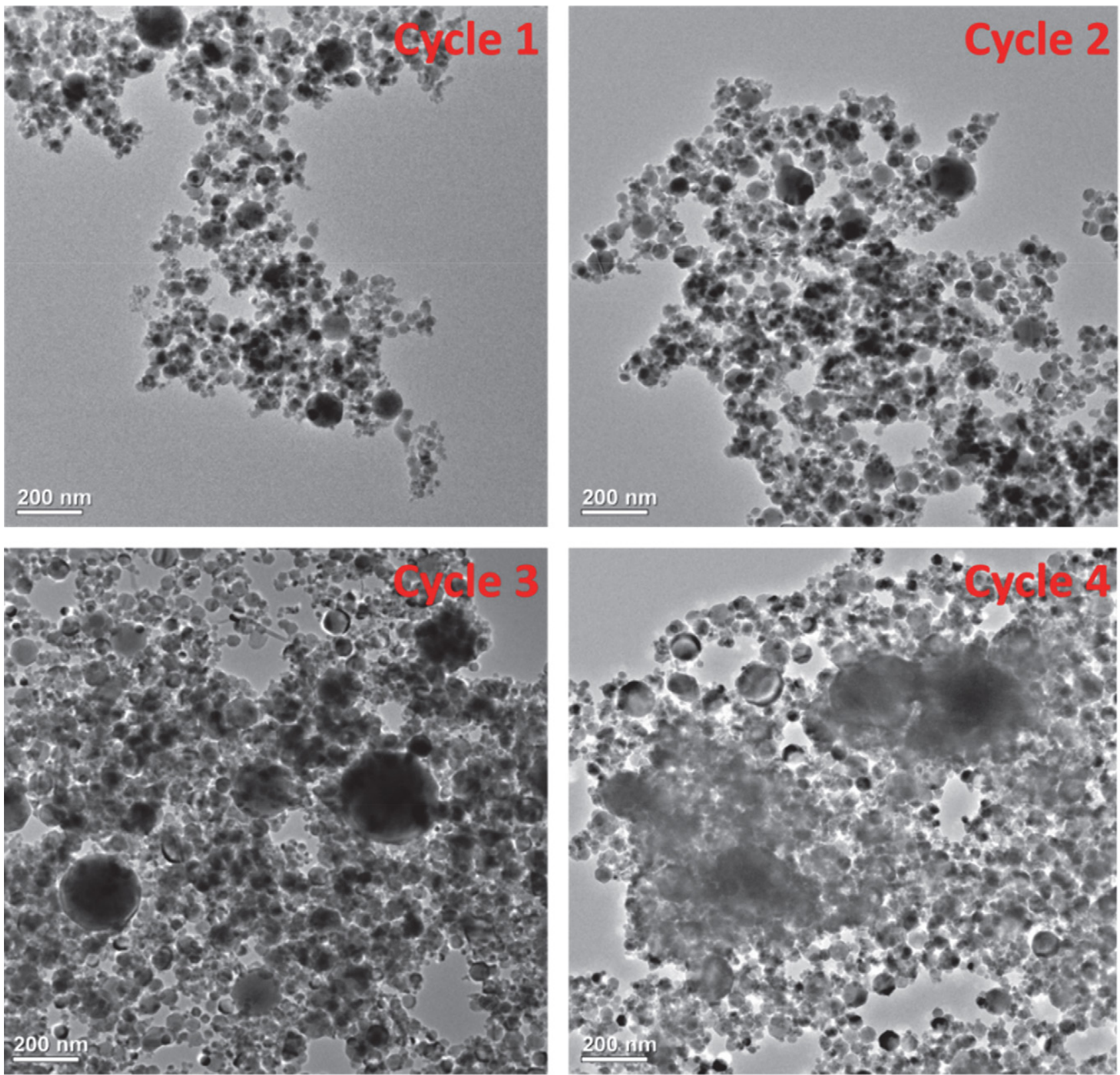

Figure 7. TEM images of $n-\mathrm{Fe}_{2} \mathrm{O}_{3}$ particles after different cycles of treatment: $[\mathrm{AB}]=[\mathrm{PX}]=0.15 \mathrm{mM} ;\left[\mathrm{n}-\mathrm{Fe}_{2} \mathrm{O}_{3}\right]=4.0 \mathrm{~g} / \mathrm{L} ;[\mathrm{HP}]=7.0 \mathrm{mM}$; treatment period $=300$ min; $\mathrm{pH}=3$.

Table 3. COD removal and $\mathrm{HP}$ consumption rate constants for the mixture of dyes $(\mathrm{AB}+\mathrm{PX})$ by $\mathrm{n}-\mathrm{Fe}_{2} \mathrm{O}_{3} / \mathrm{HP}$ system at different time intervals

\begin{tabular}{|c|c|c|c|c|}
\hline Time scale & Rate constan & $\left(10^{-3} \mathrm{~min}^{-1}\right)$ & & \\
\hline \multicolumn{5}{|c|}{ COD removal rate constants } \\
\hline & HP interference & No HP interference & HP interference & No HP interference \\
\hline $0-60(\min )$ & 1.49 & 1.32 & 0.98555 & 0.99926 \\
\hline $120-300(\mathrm{~min})$ & 7.94 & 6.73 & 0.98394 & 0.99036 \\
\hline Time scale & \multicolumn{4}{|c|}{ HP consumption rate constants } \\
\hline $0-60 \mathrm{~min}$ & 1.96 & & 0.8813 & \\
\hline $120-300 \mathrm{~min}$ & 17.17 & & 0.9684 & \\
\hline
\end{tabular}

$\mathrm{m}-\mathrm{COD}_{\mathrm{eff}}-\mathrm{COD}$ removal efficiency in the presence of residual HP $\mathrm{COD}_{\text {eff }}-\mathrm{COD}$ removal efficiency in the absence of residual $\mathrm{HP}$ 

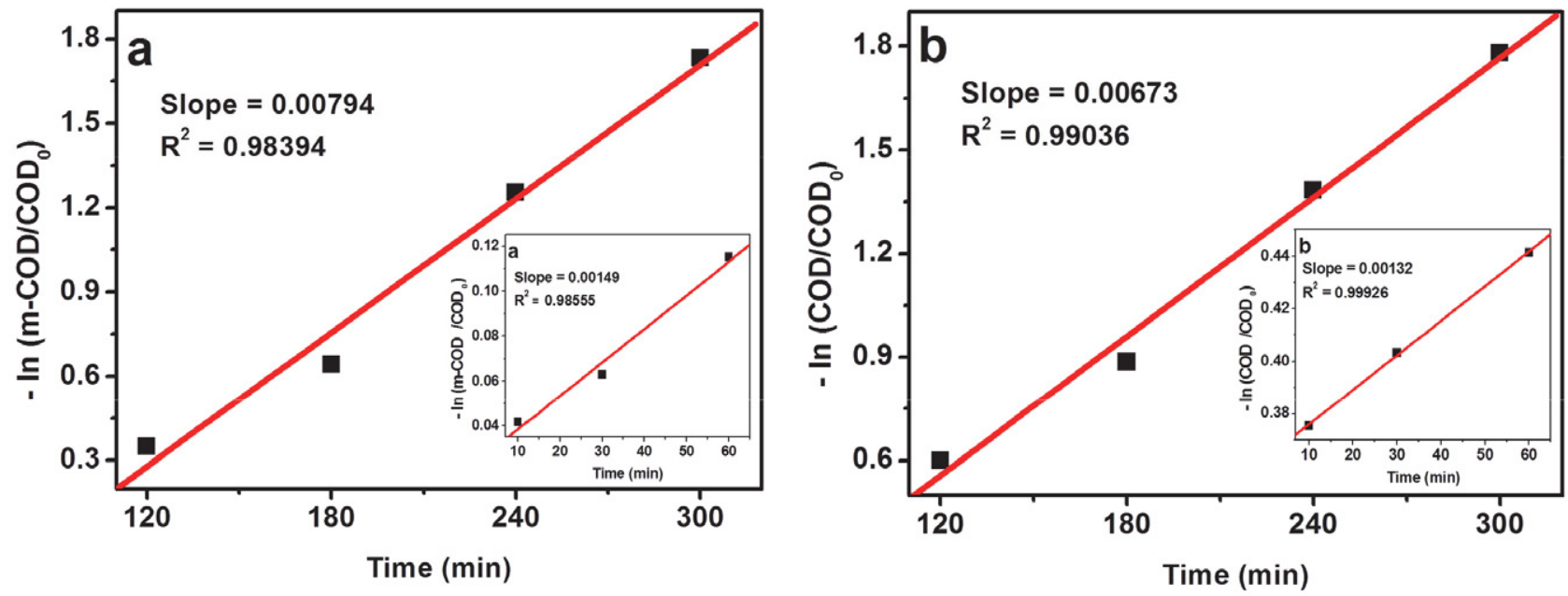

Figure 8. $\mathrm{COD}$ removal kinetics in $\mathrm{n}-\mathrm{Fe}_{2} \mathrm{O}_{3} / \mathrm{HP}$ system: (a) with interference due to HP from 120 min to 300 min (inset: from 0-60 min); (b) Without interference due to HP from 120 to $300 \mathrm{~min}$ (inset: from 0-60 min).

out HP interference established the influence of HP on the COD removal process. As discussed before, the HP used in the process was almost entirely consumed in $300 \mathrm{~min}$ of the treatment. The kinetics of HP consumption and the rate constants during $0-60$ and $120-300 \mathrm{~min}$ are given in Fig. 9 and Table 3, respectively.

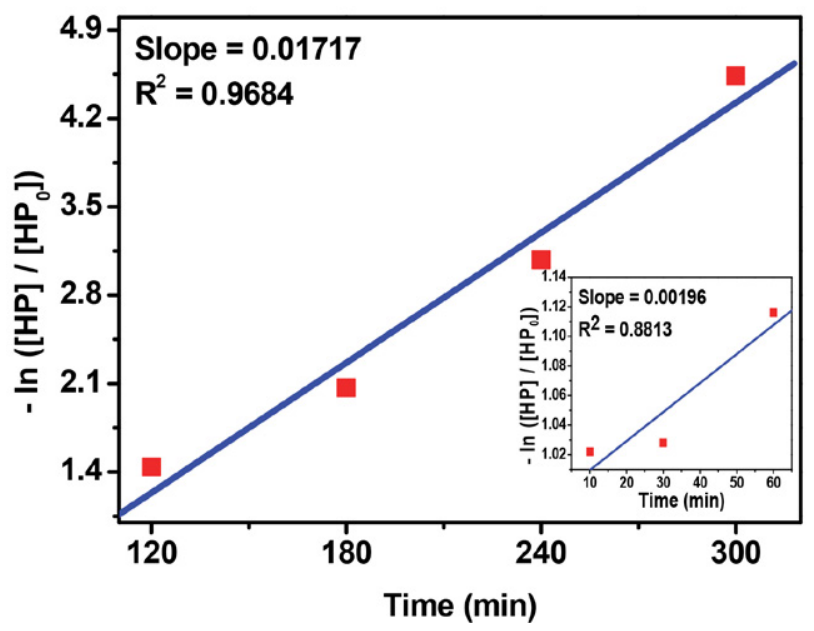

Figure 9. Kinetics of $\mathrm{HP}$ consumption in $\mathrm{n}-\mathrm{Fe}_{2} \mathrm{O}_{3} / \mathrm{HP}$ system from $120 \mathrm{~min}$ to $300 \mathrm{~min}$. (Inset: from $05 \mathrm{~min}$ to $60 \mathrm{~min}$ )

\section{7. Analysis of Ions and Intermediate Products Formed in $\mathrm{n}-\mathrm{Fe}_{2} \mathrm{O}_{3} / \mathrm{HP}$ System}

Different ions and intermediate products identified by ion chromatography during the degradation process are listed in Table 4. Both AB and PX have two sources of nitrogen: four azo nitrogen atoms on $\mathrm{AB}$ and two on $\mathrm{PX}$, one on $\mathrm{AB}$ as $-\mathrm{NO}_{2}$ substituent. The formation of $-\mathrm{Na}^{+}$as the dissociation product of both $\mathrm{AB}$ and $\mathrm{PX}$ and $\mathrm{SO}^{2-}{ }_{4}$, formed as a result of the substitution of $\mathrm{SO}^{-}$group by $\mathrm{HO}^{\circ}$ radicals has been identified. ${ }^{49-51}$ The aryl radical formed after the elimination of $\mathrm{SO}^{2-}$ gets converted to hydroxyaromatic compounds on interacting with $\mathrm{HO}^{-}$radicals. ${ }^{52}$ Apart from these ions, $\mathrm{NH}_{4}^{+}, \mathrm{NO}_{2}^{-}$and $-\mathrm{NO}^{-}{ }_{3}$ are identified in the process. The $\mathrm{NH}_{4}^{+}$ions are reported to have been formed from the azo bonds. In the first step, azo bonds are attacked by $\mathrm{HO}^{\circ}$ radicals and convert them into $-\mathrm{NH}_{2}$ groups, which accounts for the formation of aromatic amino derivatives. It may be noted that in the present case, the azo group attached to the nitrophenyl group of $\mathrm{AB}$ is electron-deficient and hence the $\mathrm{HO}^{\circ}$ radicals attack the other azo bond attached to the unsubstituted phenyl group preferentially. ${ }^{52}$ In the next step $-\mathrm{NH}_{2}$ groups undergo protonation and the subsequent attack of $\mathrm{HO}^{\circ}$ radicals at the nitrogen bearing carbon of the aromatic ring are converted into $\mathrm{NH}_{4}^{+}$ions. ${ }^{50,53}$ This accounts for the formation of phenols. There is a report that $\mathrm{N}_{2}$ is generated by the attack of $\mathrm{HO}^{\circ}$ radicals on the azo bond bearing carbon of the aromatic ring ${ }^{50}$ which accounts for an additional route to the formation of aromatic hydroxyl derivatives. The conversion of $\mathrm{NH}_{4}^{+}$to $\mathrm{NO}_{2}^{-}, \mathrm{NO}^{-}$as a result of the attack of $\mathrm{HO}^{\circ}$ radicals was suggested by Reddy and Mahajani. ${ }^{54}$ All these sequences of events are presented in Scheme 1. The formation of $\mathrm{CO}^{2-}{ }_{3}$ ions indicate the partial, if not complete, mineralisation of the dyes to carbon dioxide.

The different intermediate products identified during the process are phenol, 2- and 3-aminophenol (Table 4). A peak appeared at retention time (RT) 2.95, but could not be identified using ion chromatography. Although we have been able to identify nitro aromatic compounds in other studies (data not published), the presence of these products couldn't be established in this study. Besides these products, smaller aliphatic acids like formic acid, malonic acid, maleic acid and fumaric acid were also identified. The presence of these acids indicates that the dyes are not completely mineralised. As per another report, the attack of $\mathrm{HO}^{\circ}$ radicals to azo bond takes place with $\sim 60 \%$ probability leading to decolorisation. Successive attack on 
azo bond by $\mathrm{HO}^{\circ}$ radicals leads to the formation of nitroso (Scheme 1) followed by nitro aromatic compounds..$^{55}$ The formation of aromatic amino compounds has been described earlier. Since complete decolorisation was achieved at 360 min with a $\mathrm{COD}_{\text {eff }}$ of $83.8 \%$ by consuming $100 \% \mathrm{HP}$ (Table 2), it may be concluded that the azo bonds have broken completely, forming aromatic amines and other products (Scheme 1). Further attack of $\mathrm{HO}^{\circ}$ radicals on nitro aromatic compounds leads to the formation of hydroxybenzenes, which ultimately generate the aliphatic acids through the formation of quinones. ${ }^{56}$ The displaced $\mathrm{O}_{2} \mathrm{~N}^{\text {. }}$ radical in its term undergoes oxidation to form $\mathrm{HNO}_{3}{ }^{57}$ The attack of $\mathrm{HO}^{\circ}$ radicals onto the nitro group may also result in the formation of $\mathrm{HNO}_{3}, 52,58$ in addition to an aromatic radical, which on further interaction with $\mathrm{HO}^{\circ}$ radicals generate aromatic hydroxyl derivatives (Scheme 1).
The absence of nitro derivatives suggests that all the nitro groups are immediately substituted by $\mathrm{HO}^{\circ}$ radicals and generate aromatic hydroxyl derivatives. It is observed that phenol is obtained at $120 \mathrm{~min}$ and 2- and 3-aminophenol at $60 \mathrm{~min}$ of the reaction. This indicates that phenol is not formed from aminophenols. Instead, they are formed in different routes. Based on the above analysis and with support from literature data, ${ }^{55,59,60,}$ a mechanism of degradation of the mixture of dyes $(\mathrm{AB}+\mathrm{PX})$ has been proposed (Scheme 2).

\section{8. Comparison of Toxicity Assessed by CFU and Light Loss Measurements}

The relative toxicity of the pure dye solution and those obtained after different treatment periods in

(a) Formation of $\mathrm{SO}_{4}^{2-}$ and $\mathrm{C}_{6} \mathrm{H}_{5} \mathrm{OH}$

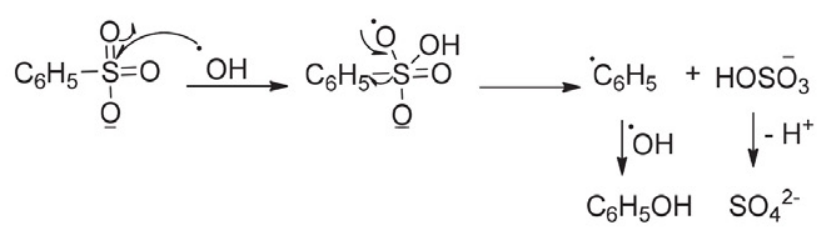

(b) Formation of Phenol, $\mathrm{NH}_{4}^{+}, \mathrm{NO}_{2}^{-}, \mathrm{NO}_{3}^{-}$
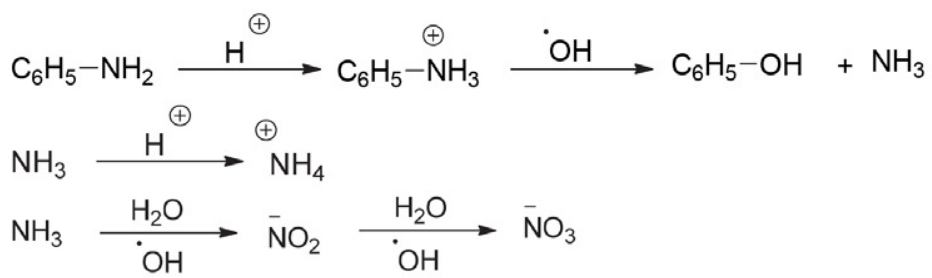

(c) Conversion of the azo bond to $-\mathrm{NH}_{2},-\mathrm{N}=\mathrm{O}$ group and $\mathrm{NO}_{2}$

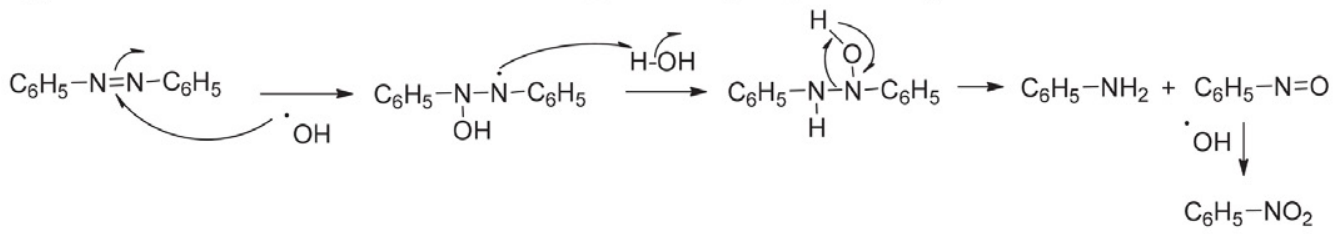

(d) Conversion of $-\mathrm{N}=\mathrm{N}$ - to phenolic group

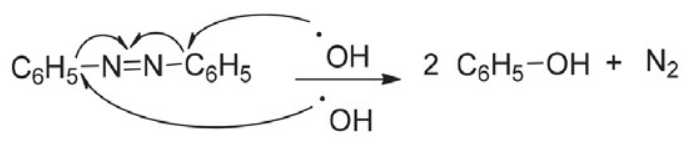

(e) Formation of phenols and amines

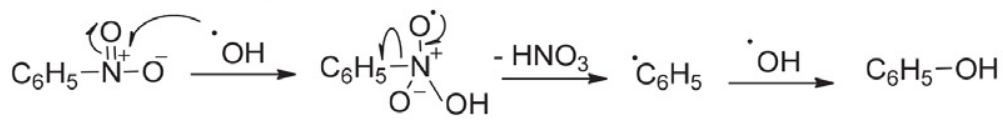



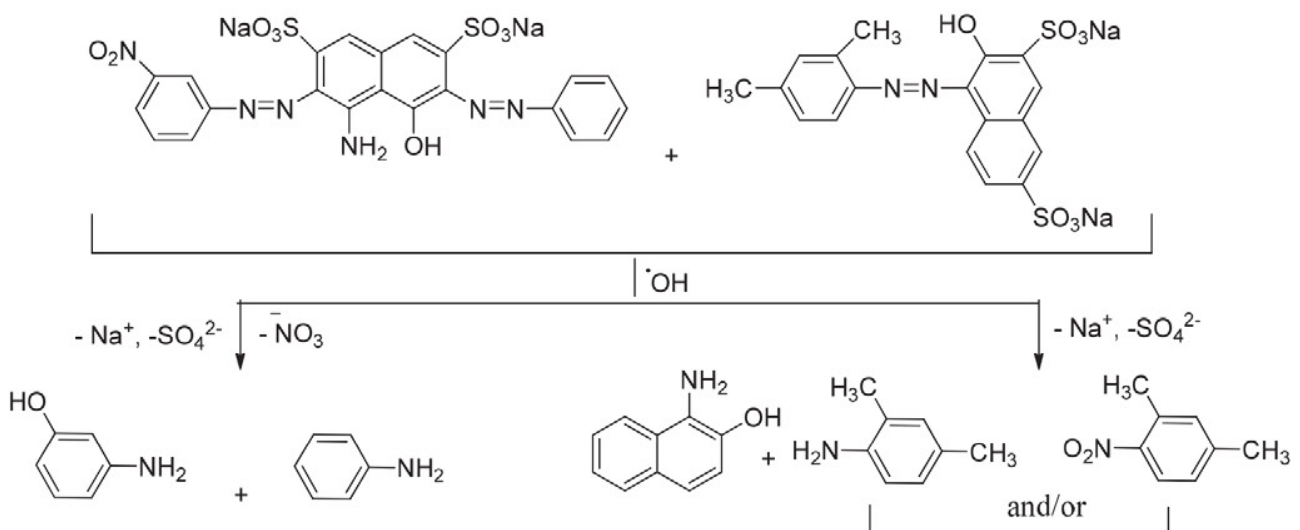<smiles>Nc1c(O)cc2cc(O)c(N)c(O)c2c1N</smiles><smiles>Nc1ccc(C(=O)O)cc1C(=O)O</smiles><smiles>C=CC</smiles><smiles>C[C@H](O)C(=O)O</smiles>
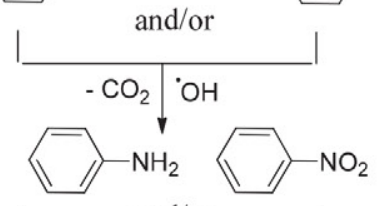
and/or OH $-{ }^{-} \mathrm{NO}_{3},-{ }^{+} \mathrm{NH}_{4}$<smiles>OC1(O)CO1</smiles><smiles>Nc1c(O)cc(C(=O)O)c(C(=O)O)c1N</smiles><smiles>Nc1cccc(O)c1N</smiles>

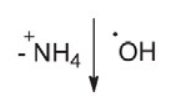<smiles>O=C1C=CCC(=O)C1O</smiles><smiles>CCc1cccc(O)c1O</smiles><smiles>O=C(O)C=CC(=O)O</smiles>

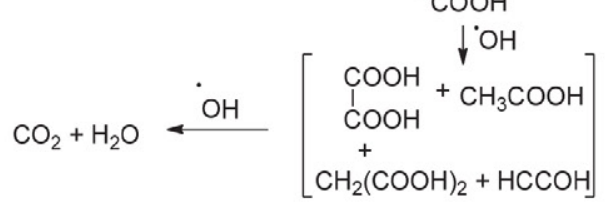<smiles>O=C(O)/C=C\C(=O)O</smiles><smiles>N#CCc1ccc(O)c([N+](=O)[O-])c1</smiles><smiles>O=C1C=CC(=O)C(C(O)O)=C1</smiles>

Scheme 2. Mechanism of degradation of the mixture of dyes $(\mathrm{AB}+\mathrm{PX})$

n- $\mathrm{Fe}_{2} \mathrm{O}_{3} / \mathrm{HP}$ system at optimal parameters was measured as a function of $\mathrm{CFU}$ and light loss percentage.

A comparison of the results by the two methods (Fig. 10) shows different relative toxicity levels for the same sample when measured with A. fischeri and E. coli. As seen from the figure, the untreated dye solution was most toxic in both assay systems. A sharp decrease in relative toxicity with an increase in treatment period was observed with the former (A. fischeri-based assay) than the later (E. coli-based assay) method. A gradual decrease was observed, indicating that both assay systems possessed differential sensitivities towards the chemical toxicity. The A. fischeri-based as- 
Table 4. Ions and intermediate products identified by ion chromatography

\begin{tabular}{|c|c|c|c|c|}
\hline \multirow{2}{*}{$\begin{array}{l}\text { Sr. } \\
\text { No. }\end{array}$} & \multicolumn{2}{|c|}{ Ions } & \multicolumn{2}{|c|}{ Intermediate products } \\
\hline & $\begin{array}{l}\text { R.T } \\
(\min )\end{array}$ & Name & $\begin{array}{l}\text { R. T } \\
(\mathrm{min})\end{array}$ & Name \\
\hline 1 & 4.27 & $\mathrm{Na}^{+}$ & 1.54 & Formic acid \\
\hline 2 & 4.54 & $\mathrm{NH}_{4}^{+}$ & 2.63 & Malonic acid \\
\hline 3 & 2.12 & $\mathrm{NO}_{2}^{-}$ & 2.81 & Maleic acid \\
\hline 4 & 3.65 & $\mathrm{NO}_{3}^{-}$ & 3.37 & Fumaric acid \\
\hline 5 & 4.26 & $\mathrm{CO}^{2-}{ }_{3}$ & 2.95 & Not identified \\
\hline 6 & 5.56 & $\mathrm{SO}^{2-}{ }_{4}$ & 3.86 & 3-Amino phenol \\
\hline 7 & - & - & 4.57 & 2- Amino phenol \\
\hline 8 & - & - & 7.91 & Phenol \\
\hline
\end{tabular}

say measured by loss of emitted fluorescence, or light, was much more sensitive than the E. coli-based assay measuring the reproductive ability of the organism expressed as CFU. Thus, the results in Fig. 10 suggest that depending on the need and circumstances, either of the two parameters may be applied to measure the extent of dye detoxification. While complete detoxification was achieved in $360 \mathrm{~min}$ based on the loss of light assay utilising A. fischeri assay system, the later assay system based on $E$. coli CFU measurements showed that the detoxification was not complete in $360 \mathrm{~min}$ and the solution still possessed about $37 \%$ relative toxicity. The different sensitivity levels of the two test systems may be attributed to an assay of diverse end points of biological parameters. Looking at the slopes of the two toxicity curves for loss of light and loss of CFU, one may postulate that E. coli, a fresh water bacterium, may be more resistant to the aromatic intermediates formed during the beginning of the reaction (Scheme 1) than A. fischeri, a marine bacterium, which could be more resistant to organic acids formed at the end of the reaction. ${ }^{61}$

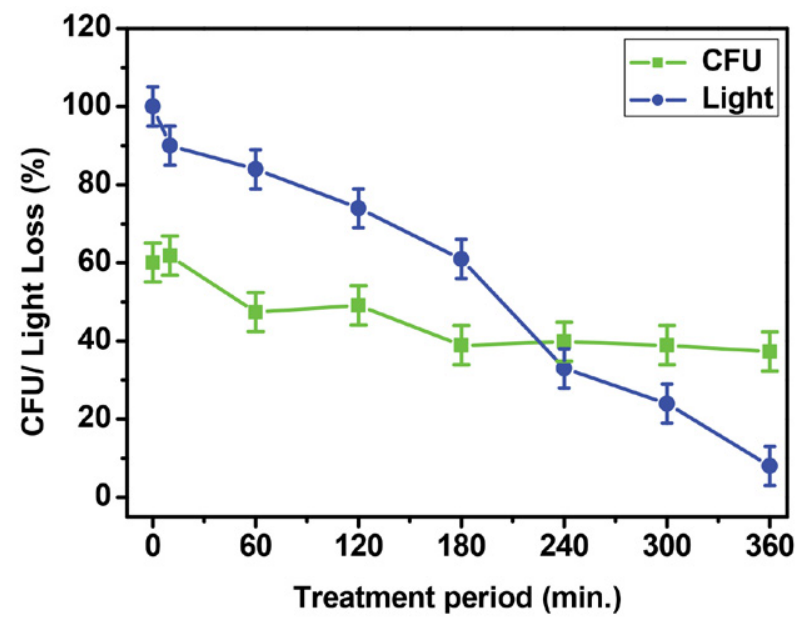

Fig. 10. E. coli and A. fischeri response in $\mathrm{n}-\mathrm{Fe}_{2} \mathrm{O}_{3} / \mathrm{HP}$ system: [AB] $=[\mathrm{PX}]=0.15 \mathrm{mM} ; \mathrm{pH}$ of treatment $=3 ; \mathrm{pH}$ of $E$. coli growth $=7$; $\left[\mathrm{n}-\mathrm{Fe}_{2} \mathrm{O}_{3}\right]=4.0 \mathrm{~g} / \mathrm{L} ;[\mathrm{HP}]=7.0 \mathrm{mM}$. Their response has been recorded as a function of CFU or light loss (\%), respectively.

\section{Conclusions}

Colour and COD removal studies of a mixture of two dyes $(\mathrm{AB}+\mathrm{PX})$ were carried out by heterogeneous Fenton process using two different types of iron oxides: $\mathrm{n}-\mathrm{Fe}_{2} \mathrm{O}_{3}$ and $\mathrm{m}-\mathrm{Fe}_{2} \mathrm{O}_{3}$ particles, and two different oxidants, $\mathrm{HP}$ and SPS. Among them, $\mathrm{n}-\mathrm{Fe}_{2} \mathrm{O}_{3}$ and $\mathrm{HP}$ were found to be the efficient catalyst and oxidant, respectively. Although, $\mathrm{m}-\mathrm{Fe}_{2} \mathrm{O}_{3}$ caused very low $\mathrm{COD}$ reduction in the presence of HP, it was completely inhibited in the presence of SPS. Decolorisation and, therefore, COD removal was accelerated in an acidic $\mathrm{pH}$ and inhibited at $\mathrm{pH}>6$ due to surface characteristics of the nano-particles. The over estimation of COD values due to the interference of $\mathrm{H}_{2} \mathrm{O}_{2}$ has been verified, and our results are in good agreement with the results reported earlier. The COD removal is a twostage process, a slow induction period and a fast degradation process, each following pseudo-first-order kinetics. The rate constants for $\mathrm{COD}_{\text {eff }}$ were found to be $1.32\left(10^{-3}\right.$ $\left.\mathrm{min}^{-1}\right)$ and $6.73\left(10^{-3} \mathrm{~min}^{-1}\right)$ during $0-60$ and $120-300$ min respectively after eliminating the interference due to $\mathrm{HP}$ and those for HP consumption during 0-60 and 120$300 \mathrm{~min}$ were found to be 1.96 and $17.17\left(10^{-3} \mathrm{~min}^{-1}\right)$.

The catalyst's efficiency decreased from the $3^{\text {rd }}$ cycle onwards due to various factors, such as lower leaching of iron resulting in a lower contribution to homogeneous Fenton process, catalyst surface area reduction due to agglomeration, deactivation of active sites by adsorption of organic intermediates etc. Hence, more work is required to identify the exact causes of deactivation, find some regeneration measures to restore the catalyst efficiency. The different ions formed during the process were identified as $\mathrm{Na}^{+}, \mathrm{SO}^{2-}{ }_{3}, \mathrm{NH}_{4}^{+}, \mathrm{NO}^{-}{ }_{2}$ and $\mathrm{NO}^{-}{ }_{3}$ and the intermediate products as phenol, 2- and 3-aminophenol, formic acid, malonic acid, maleic acid and fumaric acid. Using two different toxicity assays, $A$. fischeri assay system measuring fluorescence and $E$. coli assay system giving CFU measurement, we found differential expression of relative toxicities for the same solution.

\section{Acknowledgements}

The authors gratefully acknowledge the use of facilities acquired through the DAE-BRNS grant (2013/36/50BRNS/2485, dated 05.12.2013) to MKS; DST-FIST grant (SR/FST/CSI-194-2008) of the Department of Science and Technology, Govt. of India and UGC-SAP CAS-I grant (F.540/21/CAS/2013(SAP I)) of UGC to the Department of Chemistry, North-Eastern Hill University (NEHU), Shillong. The services provided by the Sophisticated Analytical Instrumentation Facility, NEHU for TEM, EDX and ICP-OES analysis and Department of Nanotechnology, NEHU for XRD measurements are duly acknowledged. It is further declared that this research did not receive any specific grant from funding agencies in the public, commercial, or not-for-profit sectors. 


\section{References}

1. A. Yadav, S. Mukherji, A. Garg, Ind. Eng. Chem. Res. 2013, 52, 10063-10071. DOI:10.1021/ie400855b

2. A. Eslami, M. Moradi, F. Ghanbari, F. Mehdipour, J. Environ. Health Sci. Eng. 2013, 11, 1-8.

DOI:10.1186/2052-336X-11-31

3. I. Oller, S. Malato, J. A. Sánchez-Pérez, Sci. Total Environ. 2011, 409, 4141-4166. DOI:10.1016/j.scitotenv.2010.08.061

4. P. Ghosh, A. N. Samanta, S. Ray, Can. J. Chem. Eng. 2010, 88, 1021-1026. DOI:10.1002/cjce.20353

5. A. Durán, J. M. Monteagudo, I. S. Martén, F. J. Amunategui, D. A. Patterson, Chemosphere, 2017, 186, 177-184.

DOI:10.1016/j.chemosphere.2017.07.148

6. X. -R. Xu, X. -Z. Li, Sep. Purif. Technol. 2010, 72, 105-111. DOI:10.1016/j.seppur.2010.01.012

7. M. K. Sahoo, J. E. Kumar, B. Sinha, M. Marbaniang, R. N. Sharan, Water Sci. Tech. 2018, 77, 2917-2928.

DOI:10.2166/wst.2018.290

8. F. Haber, J. Weiss, Proc. Roy. Soc. A, 1934, 147, 332-351. DOI:10.1098/rspa.1934.0221

9. G. P. Anipsitakis, D. D. Dionysiou, Environ. Sci. Technol. 2004, 38, 3705-3712. DOI:10.1021/es035121o

10. I. Grčić, S. Papić, K. Žižek, N. Koprivanac, Chem. Eng. J. 2012, 195/196, 77-90. DOI:10.1016/j.cej.2012.04.093

11. L. Xu, J. Wang, J. Hazard. Mater. 2011, 186, 256-264. DOI:10.1016/j.jhazmat.2010.10.116

12. Y. Wang, Y. Gao, L. Chen, Catal. Today, 2015, 252, 107-112. DOI:10.1016/j.cattod.2015.01.012

13. M. C. Pereira, L. C. A. Oliveira, E. Murad, Clay Miner. 2012, 47, 285-302. DOI:10.1180/claymin.2012.047.3.01

14. S. P. Sun, A. T. Lemley, J. Mol. Catal. A: Chem. 2011, 349, 71-79. DOI:10.1016/j.molcata.2011.08.022

15. X. Xue, K. Hanna, N. Deng, J. Hazard. Mater. 2009, 166, 407414. DOI:10.1016/j.jhazmat.2008.11.089

16. D. B. Hasan, S. R. Pouran, A. R. A. Aziz, S. M. Nashwan, W. M. A. W. Daud, M. G. Shaaban, J. Indust. Eng. Chem. 2015, 25, 186-191. DOI:10.1016/j.jiec.2014.10.033

17. S. Sarkar, A. Banerjee, U. Halder, R. Biswas, R. Bandopadhyay, Water Conserv. Sci. Eng. 2017, 2, 121-131.

DOI:10.1007/s41101-017-0031-5

18. R. G. Saratale, G. D. Saratale, J. S. Chang, J. Taiwan Inst. Chem. Eng. 2011, 42, 138-157. DOI:10.1016/j.jtice.2010.06.006

19. X. Yi, E. Kim, H. J. Jo, D. Schlenk, J. Jung, Ecotoxicol. Environ. Saf. 2009, 72, 1919-1924. DOI:10.1016/j.ecoenv.2009.04.012

20. M. K. Sahoo, B. Sinha, M. Marbaniang, D. B. Naik, R. N. Sharan, Chem. Eng. J. 2012, 209, 147-154.

DOI:10.1016/j.cej.2012.07.121

21. R. Massart, IEEE Trans. Magn. 1981, 17, 1247-1248. DOI:10.1109/TMAG.1981.1061188

22. Y. W. Kang, M. -J. Cho, K. -Y. Hwang, Water Res. 1999, 33, 1247-1251. DOI:10.1016/S0043-1354(98)00315-7

23. APHA, Standard methods for the examination of water and wastewater. 19th Ed. Wahington DC, New York, 1995.

24. Y. Zhang, N. Zhang, T. Wang, H. Huang, Y. Chen, Z. Li, Z. Zou, Appl. Catal. B: Environ. 2019, 245, 410-419.
DOI:10.1016/j.apcatb.2019.01.003

25. R. N. Sharan, H. Ryo, T. Nomura, Int. J. Radiat. Biol. 2007, 83, 89-97. DOI:10.1080/09553000601121140

26. A. Karczmarczyk, A. Celebanska, W. Nogala, V. Sashuk, O. Chernyaeva, M. Opallo, Electrochim. Acta, 2014, 117, 211216. DOI:10.1016/j.electacta.2013.11.049

27. T. X. H. Le, T.V. Nguyen, Z. A. Yacouba, L. Zoungrana, F. Avril, E. Petit, J. Mendret, V. Bonniol, M. Bechelany, S. Lacour, G. Lesage, M. Cretin, Chemosphere, 2016, 161 308-318. DOI:10.1016/j.chemosphere.2016.06.108

28. S. M. El-Khouly, N. A. Fathy, Asia-Pac. J. Chem. Eng. 2018, 13, 1-11. DOI:10.1002/apj.2184

29. P. Djomgoue, D. Njopwouo, J. Surf. Eng. Mater. Adv. Technol. 2013, 3, 275-282. DOI:10.4236/jsemat.2013.34037

30. C. Liang, H. Liu, J. Zhou, X. Peng, H. Zhang, J. Chem. 2015, 2015, 1-8. DOI:10.1155/2015/791829

31. A. Phuruangrat, A. Maneechote, P. Dumrongrojthanath, N. Ekthammathat, S. Thongtem, T. Thongtem, Superlattice. Microstruct. 2015, 78 106-115.

DOI:10.1016/j.spmi.2014.11.038

32. P. Dumrongrojthanath, T. Thongtem, A. Phuruangrat, S. Thongtem, Superlattice. Microstruct. 2013, 64, 196-203. DOI:10.1016/j.spmi.2013.09.028

33. N. K. Daud, B. H. Hameed, J. Hazard. Mater. 2010, 176, 938 944. DOI:10.1016/j.jhazmat.2009.11.130

34. N. Masomboon, C. Ratanatamskul, M. C. Lu, Environ. Sci. Technol. 2009, 43, 8629-8634. DOI:10.1021/es802274h

35. S. X. Zhang, X. L. Zhao, H. Y. Niu, Y. L. Shi, Y. Q. Cai, G. Jiang, J. Hazard. Mater. 2009, 167, 560-566.

DOI:10.1016/j.jhazmat.2009.01.024

36. H. Watanabe, J. Seto, Bull. Chem. Soc. Jpn. 1986, 59, 26832687. DOI:10.1246/bcsj.59.2683

37. G. V. Buxton, C. L. Greenstock, W. P. Helman, A. B. Ross, J. Phys. Chem. Ref. Data, 1988, 17, 513-886.

DOI:10.1063/1.555805

38. S. R. Pouran, A. Bayrami, M. S. Shafeeyan, A. A. B. Raman, W. M. A. W. Daud, Acta Chim. Slov. 2018, 65, 166-171.

DOI:10.17344/acsi.2017.3732

39. F. Velichkova, C. Julcour-Lebigue, B. Koumanova, H. Delmas, J. Environ. Chem. Eng. 2013, 1, 1214-1222.

DOI:10.1016/j.jece.2013.09.011

40. K. Rusevova, F. D. Kopinke, A. Georgi, J. Hazard. Mater. 2012, 241/242, 433-440. DOI:10.1016/j.jhazmat.2012.09.068

41. D. N. Thi, H. P. Ngoc, H. D. Manh, T. N. Kim, J. Hazard. Mater. 2011, 185, 653-661. DOI:10.1016/j.jhazmat.2010.09.068

42. J. H. Ramirez, F. J. Maldonado-Hódar, A. F. Pérez-Cadenas, C. Moreno-Castilla, C. A. Costa, L. M. Madeira, Appl. Catal. B: Environ. 2007, 75, 312-323.

DOI:10.1016/j.apcatb.2007.05.003

43. L. Xua, J. Wang, Appl. Catal. B: Environ. 2012, 123-124, 117126. DOI:10.1016/j.apcatb.2012.04.028

44. T. R. Gordon, A. L. Marsh, Catal. Lett. 2009, 132, 349-354. DOI:10.1007/s10562-009-0125-6

45. S. Das, P. V. Kamat, S. Padmaja, V. Au, S. A. Madison, Free radical induced oxidation of the azo dye Acid Yellow 9, J. Chem. Soc. Perkin Trans. 1999, 2, 1219-1224. 
DOI: $10.1039 / \mathrm{a} 809720 \mathrm{~h}$

46. J. T. Spadaro, L. Isabelle, V. Renganathan, Environ. Sci. Technol. 1994, 28, 1389-1393. DOI:10.1021/es00056a031

47. J. Guo, M. Al-Dahhan, Appl. Catal. A, 2006, 299, 175-184. DOI:10.1016/j.apcata.2005.10.039

48. S. P. Yeap, J. Lim, B. S. Ooi, A. Ahmad, J. Nanopart Res. 2017, 368, 1-15. DOI:10.1007/s11051-017-4065-6

49. M. Karkmaz, E. Puzenat, C. Guillard, J. M. Herrmann, Appl. Catal. B: Environ. 2004, 51, 183-194.

DOI:10.1016/j.apcatb.2004.02.009

50. H. Lachheb, E. Puzenat, A. Houas, M. Ksibi, E. Elaloui, C. Guillard, J. Herrmann, Appl. Catal. B: Environ. 2002, 39, 7590. DOI:10.1016/S0926-3373(02)00078-4

51. C. Galindo, P. Jacques, A. Kalt, J. Photochem. Photobiol. A: Chem. 2000, 130, 35-47.

DOI:10.1016/S1010-6030(99)00199-9

52. M. A. Meetani, S. M. Hisaindee, F. Abdullah, S. S. Ashraf, M. A. Rauf, Chemosphere, 2010, 80, 422-427.

DOI:10.1016/j.chemosphere.2010.04.065

53. K. Sahel, N. Perol, H. Chermette, C. Bordes, Z. Derriche, C. Guillard, Appl. Catal. B-Environ. 2007, 77, 100-109.

DOI:10.1016/j.apcatb.2007.06.016
54. G. R. Reddy, V. V. Mahajani, Ind. Eng. Chem. Res. 2005, 44, 7320-7328. DOI:10.1021/ie050438d

55. J. M. Joseph, H. Destaillats, H. -M. Hung, M. R. Hoffmann, J. Phys. Chem. A. 2000, 104, 301-307. DOI:10.1021/jp992354m

56. J. H. Fendler, G. L. Gasowski, J. Org. Chem. 1968, 33, 18651868. DOI:10.1021/jo01269a035

57. A. Kotronarou, G. Mills, M. R. Hoffmann, J. Phys. Chem. 1991, 95, 3630-3638. DOI:10.1021/j100162a037

58. M. Holčapek, K. Volná, D. Vaněrková, Dyes Pigm. 2007, 75, 156-165. DOI:10.1016/j.dyepig.2006.05.040

59. J. R. Steter, W. R. P. Barros, M. R. V. Lanza, A. J. Motheo, Chemosphere, 2014, 117, 200-207.

DOI:10.1016/j.chemosphere.2014.06.085

60. E. Neyens, J. Baeyens, J. Hazard. Mater. B, 2003, 98, 33-50. DOI:10.1016/S0304-3894(02)00282-0

61. M. Munoz, Z. M. de Pedro, J. A. Casas, J. J. Rodriguez, Chem. Eng. J. 2012, 198-199, 275-281.

DOI:10.1016/j.cej.2012.05.097

\section{Povzetek}

Preučevali smo odstranjevanje mešanice dveh azo barvil, »adic blue 29 « in "ponceau xylidine« (imenovano tudi »acid red 26«), s pomočjo heterogenega Fentonovega in Fentonu podobnega procesa $\mathrm{z}$ uporabo vodikovega peroksida in natrijevega persulfata kot oksidanta, v prisotnosti katalizatorja v obliki nano in mikro $\mathrm{Fe}_{2} \mathrm{O}_{3}$ delcev. Sintetizirane $\mathrm{Fe}_{2} \mathrm{O}_{3}$ delce smo okarakterizirali z uporabo FT-IR, TEM, EDX, praškovne XRD in VSM. Preučili smo vpliv velikosti delcev na zmanjševanje COD (kemijske potrebe po kisiku), kot tudi večkratnosti uporabe katalizatorja po optimizaciji pH vrednosti ter koncentracije katalizatorja in oksidanta. Kombinacija nano- $\mathrm{Fe}_{2} \mathrm{O}_{3}$ in vodikovega peroksida se je izkazala kot najučinkovitejša za zmanjševanje COD, ki je bila hitrejša v kislem območju in inhibirana pri $\mathrm{pH}>6$. Celokupna poraba vodikovega peroksida je potrdila učinkovitost procesa pod optimiziranimi pogoji. Predpostavili smo reakcijski mehanizem nastajanja vmesnih ionov in produktov. Zmanjševanje COD in vodikovega peroksida je sledilo kinetiki pseudo-prvega reda. Toksičnost raztopine smo preverjali preko zmanjševanja svetilnosti Aliivibrio fischeri in inhibicije rasti Escherichia coli. Metodi sta pokazali različno stopnjo toksičnosti iste raztopine.

Except when otherwise noted, articles in this journal are published under the terms and conditions of the Creative Commons Attribution 4.0 International License 